\title{
Hydrological trade-offs due to different land covers and land uses in the Brazilian Cerrado
}

\author{
Jamil A. A. Anache ${ }^{1}$, Edson Wendland ${ }^{1}$, Lívia M. P. Rosalem ${ }^{1}$, Cristian Youlton ${ }^{1}$, and Paulo T. S. Oliveira ${ }^{2}$ \\ ${ }^{1}$ Department of Hydraulics and Sanitation, São Carlos School of Engineering (EESC), \\ University of São Paulo (USP), CxP. 359, São Carlos, SP, 13566-590, Brazil \\ ${ }^{2}$ Federal University of Mato Grosso do Sul, CxP. 549, Campo Grande, MS, 79070-900, Brazil
}

Correspondence: Jamil A. A. Anache (jamil.anache@usp.br)

Received: 3 August 2018 - Discussion started: 29 August 2018

Revised: 7 December 2018 - Accepted: 11 February 2019 - Published: 7 March 2019

\begin{abstract}
Farmland expansion in the Brazilian Cerrado, considered one of the largest agricultural frontiers in the world, has the potential to alter water fluxes on different spatial scales. Despite some large-scale studies being developed, there are still few investigations in experimental sites in this region. Here, we investigate the water balance components in experimental plots and the groundwater table fluctuation in different land covers: wooded Cerrado, sugarcane, pasture and bare soil. Furthermore, we identify possible water balance trade-offs due to the different land covers. This study was developed between 2012 and 2016 in the central region of the state of São Paulo in southern Brazil. Hydrometeorological variables, groundwater table, surface runoff and other water balance components were monitored inside experimental plots containing different land covers; the datasets were analyzed using statistical parameters; and the water balance components uncertainties were computed. Replacing wooded Cerrado by pastureland and sugarcane shifts the overland flow (up to $42 \mathrm{~mm} \mathrm{yr}^{-1}$ ) and the water balance residual (up to $504 \mathrm{~mm} \mathrm{yr}^{-1}$ ) and may affect groundwater table behavior. This fact suggests significant changes in the water partitioning in a transient land cover and land use (LCLU) system, as the evapotranspiration is lower (up to $719 \mathrm{~mm} \mathrm{yr}^{-1}$ ) in agricultural land covers than in the undisturbed Cerrado. We recommend long-term observations for continuing the evaluations initiated in this study, mainly because there are few basic studies on tropical environments at the hillslope scale and more assessments are needed for a better understanding of the real field conditions. Such efforts should be made to reduce uncertainties, validate the water
\end{abstract}

balance hypothesis and catch the variability of hydrological processes.

\section{Introduction}

Brazil has significant areas used for extensive grazing over pasture and farmland (mainly soybeans and sugarcane), and parts of these areas were mostly occupied by the native Cerrado, which decreased significantly in the last century (Marris, 2005). It is estimated that $52.2 \%$ of the original Cerrado area is now occupied by pasturelands and croplands, $0.8 \%$ is occupied by other land uses, and $47 \%$ remains undisturbed (Beuchle et al., 2015). The conversion from native Cerrado to pastureland, and afterwards, to sugarcane, can be considered a potential land cover and land use change (LCLUC) in southeastern Brazil (Alkimim et al., 2015). However, few studies investigate the effects of the LCLUC dynamics (Bonan, 2008; Loarie et al., 2011; Grecchi et al., 2014).

In the state of São Paulo, the minimum area required by the Brazilian forest code to maintain native forests in the Cerrado biome ( $20 \%$ of the total area of a state) is not reached in much of the state (Soares-Filho et al., 2014). These areas were primary resources for expansion of the agricultural frontier in the tropics (Gibbs et al., 2010; Lapola et al., 2013), and these changes may cause significant disturbances in the hydrological processes (Loarie et al., 2011; Oliveira et al., 2014, 2015; Nobrega et al., 2017). These processes in tropical and subtropical zones are different from other regions across the world due to the increased solar energy availability and rainfall, calling for the need of basic field studies, 
long-term data acquisition and availability, and the development and application of mathematical models (Wohl et al., 2012; Burt and McDonnell, 2015).

In the context of the Cerrado biome, the conversion of undisturbed vegetation and pasturelands to mechanized crop systems (e.g., sugarcane, corn and soybeans) indicates that this region in Brazil has a dynamic LCLUC situation (Lapola et al., 2013). The sugarcane is the Brazilian backbone for energy security, as the ethanol production is the third-most cultivated crop after soybeans and corn, reflecting the increasing demand for automotive fuels over the years (Leal et al., 2013; Rodrigues et al., 2018). Thus, the country is the world's second largest ethanol producer, and the Cerrado comprises the sugarcane expansion frontier due to the availability of water and pasturelands for the crop expansion (Bellezoni et al., 2018).

Native forests help in maintaining the water cycle $(\mathrm{Kr}$ ishnaswamy et al., 2013; Ghimire et al., 2014). The evapotranspiration appears to be a key component in the aquifer recharge control in the Guarani aquifer system (GAS) outcrop zone (Wendland et al., 2007; Lucas and Wendland, 2015; Lucas et al., 2015). Thus, water partitioning in these areas should be well understood in different land cover and land use (LCLU) types, allowing the evaluation of possible water balance trade-offs due to the LCLUC (Krishnaswamy et al., 2013; Ghimire et al., 2014; Frank et al., 2014) caused by environmental and economic needs (Barretto et al., 2013).

In Brazil, many large-scale studies on water balance were developed in some hydrographic regions in the country (Paiva et al., 2013; da Paz et al., 2014; Oliveira et al., 2014; Melo et al., 2016). Nevertheless, experiment-scale studies are still rare due to the local heterogeneities and uncertainties from hydrological measurements and estimates (Beven, 2006; Graham et al., 2010). Basic field-hydrology studies are important for improving the agricultural production efficiency while promoting sustainable development. Therefore, these studies are important for promoting new solutions and techniques to maintain the water balance in spite of the rapid LCLUC (Dotterweich, 2013; Nobrega et al., 2017). Research of this kind can be done using experimental plots, which are delimitated hillslopes (control volume) where the overland flow is directed to one outlet (Sadeghi et al., 2013; Oliveira et al., 2015, 2016; Mwango et al., 2016; Strohmeier et al., 2016; Youlton et al., 2016b; Anache et al., 2017, 2018; Zhao et al., 2017).

The objective of this study is to evaluate the water fluxes in different LCLU types: wooded Cerrado (also known as Cerrado sensu stricto), sugarcane, pasture and bare soil. In addition, we identify possible water balance trade-offs due to the different LCLU types, compute the uncertainties for each water balance component and propagate the error separately for each LCLU.

\section{Material and methods}

\subsection{Study sites and regional setting}

The study sites are located in the Arruda Botelho Institute (IAB) in Itirapina, São Paulo, Brazil (latitude $22^{\circ} 11^{\prime} 5^{\prime \prime} \mathrm{S}$, longitude $47^{\circ} 51^{\prime} 11^{\prime \prime} \mathrm{W}$; elevation $790 \mathrm{~m}$ a.m.s.l.; Fig. 1). The area is inside two major hydrological hotspots in the country: the Guarani aquifer system (GAS; Wendland et al., 2007; Oliveira et al., 2017) outcrop zone and the Cerrado biome. Site 1 is located under agricultural land covers (pasture, sugarcane and bare soil), while site 2 is located under the wooded Cerrado. The climate in the region is humid subtropical (Cwa, Köppen), with a hot and wet summer and a dry winter (Alvares et al., 2014). The average annual rainfall and temperature are $1486 \mathrm{~mm} \mathrm{yr}^{-1}$ and $21.5^{\circ} \mathrm{C}$, respectively (Cabrera et al., 2016). Additionally, the soil is sandy, and it is classified as an entisol (Oliveira et al., 2016); its saturated hydraulic conductivity ranges from 11.30 to $147.31 \mathrm{~mm} \mathrm{~h}^{-1}$ along the superficial layer (first meter; Oliveira, 2014; Youlton et al., 2016b).

\subsection{Experimental setting and instrumentation}

The experiment began in October 2011 (Oliveira et al., 2015, 2016; Youlton et al., 2016b, a), and it is still in operation. This study considered the data collected during 5 years (2012-2016). It contains manual and automatic instruments, as well as permanent structures, all assembled in the two sites (Fig. 2). Two monitoring wells, meteorological stations (tripod and tower), and 12 steel-made bounded plots are the permanent structure. The instruments are described according to their positioning and function (Table 1). All instruments recorded data every $10 \mathrm{~min}$, except the pressure transducers, which logged the groundwater table twice a day. The distance between sites 1 and 2 is $1.7 \mathrm{~km}$. Site 1 has nine plots placed side by side (approximately $2.5 \mathrm{~m}$ of distance between each plot). Also in site 1 , there is a meteorological station that concentrates almost all sensors placed at that site at one point, except for the soil moisture probes. They are connected to the meteorological station, but they are placed inside the plots (there is one placed inside the first sugarcane plot, and $20 \mathrm{~m}$ to the left, there is another one placed inside the first pasture plot). Site 2 has three plots inside a tropical woodland (wooded Cerrado), and due to the tree density and topography, the plots are approximately 5 to $10 \mathrm{~m}$ distant from each other. Approximately $50 \mathrm{~m}$ to the north of the plots, there is a meteorological tower (11 $\mathrm{m}$ height) containing all the sensors placed at site 2 .

The plots were designed to adequately represent the process heterogeneities (Sadeghi et al., 2013): three replicates for each LCLU, with $5 \mathrm{~m}$ width, $20 \mathrm{~m}$ length and a $9 \%$ slope gradient. The plots located at site 1 contain three different LCLU types, including (i) pasture (Brachiaria decumbens) established 20 years ago, used for grazing and plant heights 


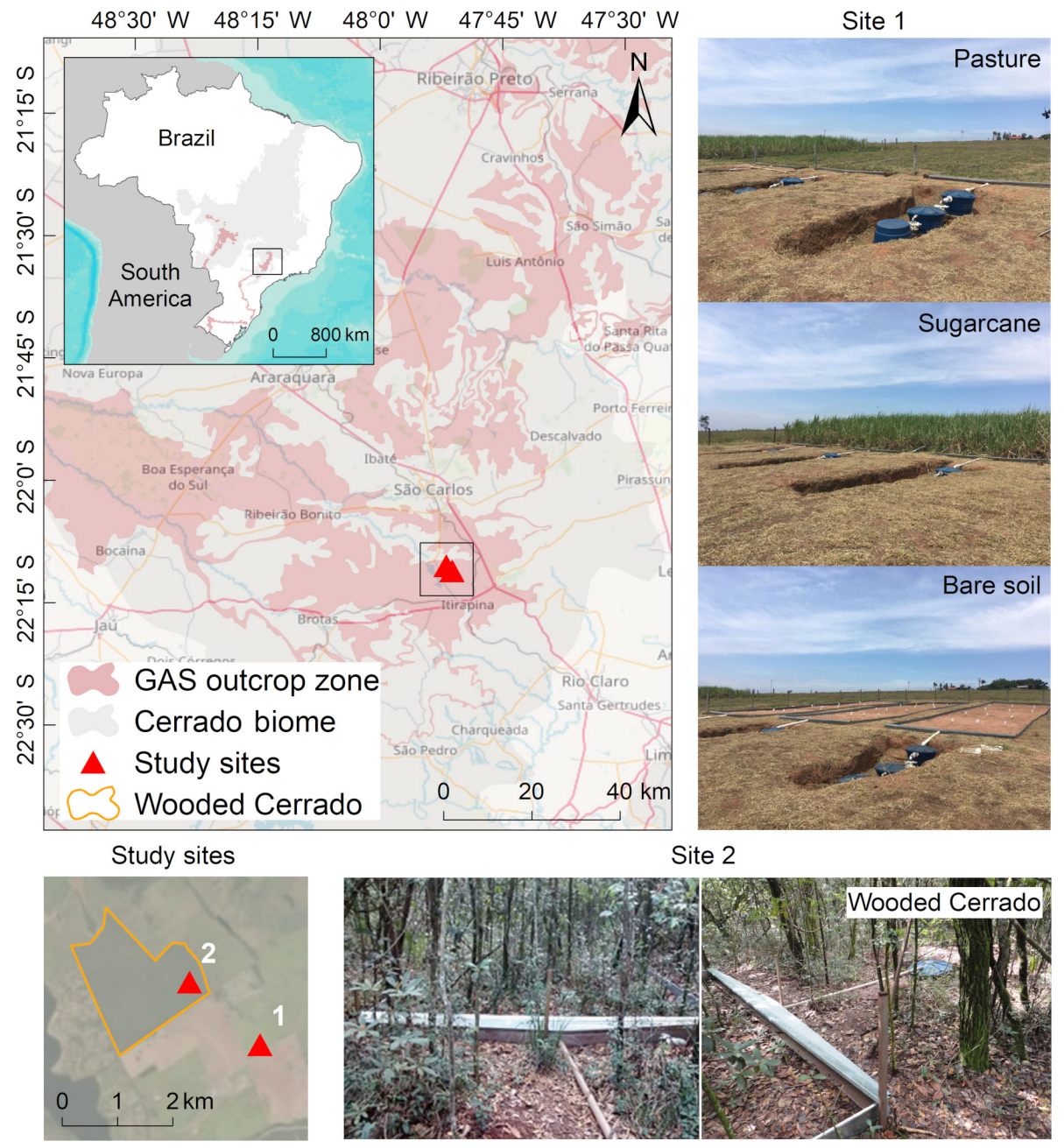

Figure 1. Location of study sites, Cerrado biome borders, Guarani aquifer system (GAS) outcrop zone distribution in Brazil, and experimental design, where site 1 contains the plots with agricultural land uses (pasture, sugarcane and bare soil) and site 2 contains the plots with wooded Cerrado.

varying between 5 and $30 \mathrm{~cm}$. The animals' (cattle) rotation period is 30 days (10 animals per hectare), and each one weighs approximately $420 \mathrm{~kg}$. The animals remain in the area for 5 days in each rotation; (ii) contoured planted sugarcane (Saccharum officinarum) is found on beds spaced $1.5 \mathrm{~m}$ apart. The plantation was established in October 2011, and the canopy reaches at least $2 \mathrm{~m}$ high and was harvested every November; (iii) bare soil plots were maintained without plant cover by manual tillage and glyphosate application. The plots located at site 2 have the same experimental design as site 1 and contain (iv) wooded Cerrado as vegetation. The Cerrado comprises tropical vegetation in which the trees do not form a continuous canopy; however, it presents woody components that are 6 to $7 \mathrm{~m}$ high (Alberton et al., 2014). The Cerrado vegetation is fire-resistant, and it is considered a biodiversity hotspot and supports long dry periods (Brannstrom et al., 2008). Concerning the woodland characteristics, the wooded Cerrado area used in this study has 15522 individual trees per hectare, the height of most of the trees is about $8 \mathrm{~m}$, and the tree diameter at breast height $(\mathrm{DBH})$ is predominantly between 3 and $7 \mathrm{~cm}$ (Reys et al., 2013). The soil root zone in the wooded Cerrado may reach up to $18 \mathrm{~m}$ (Rawitscher, 1948). However, most of the water used for plants' transpiration comes from the first layers (up to $7.5 \mathrm{~m}$; Canadell et al., 1996; Oliveira et al., 2005; Garcia-Montiel et al., 2008).

\subsection{Water balance components}

The water balance components (Eq. 1) were monitored over 5 years (2012-2016) in a control volume defined by the bounded plots placed within the experimental sites. We considered different techniques for monitoring these components according to the LCLU conditions. The water balance residual $(\mathrm{d} S / \mathrm{d} t)$ includes subsurface flow, soil water storage, deep percolation, and groundwater recharge. This is repre- 


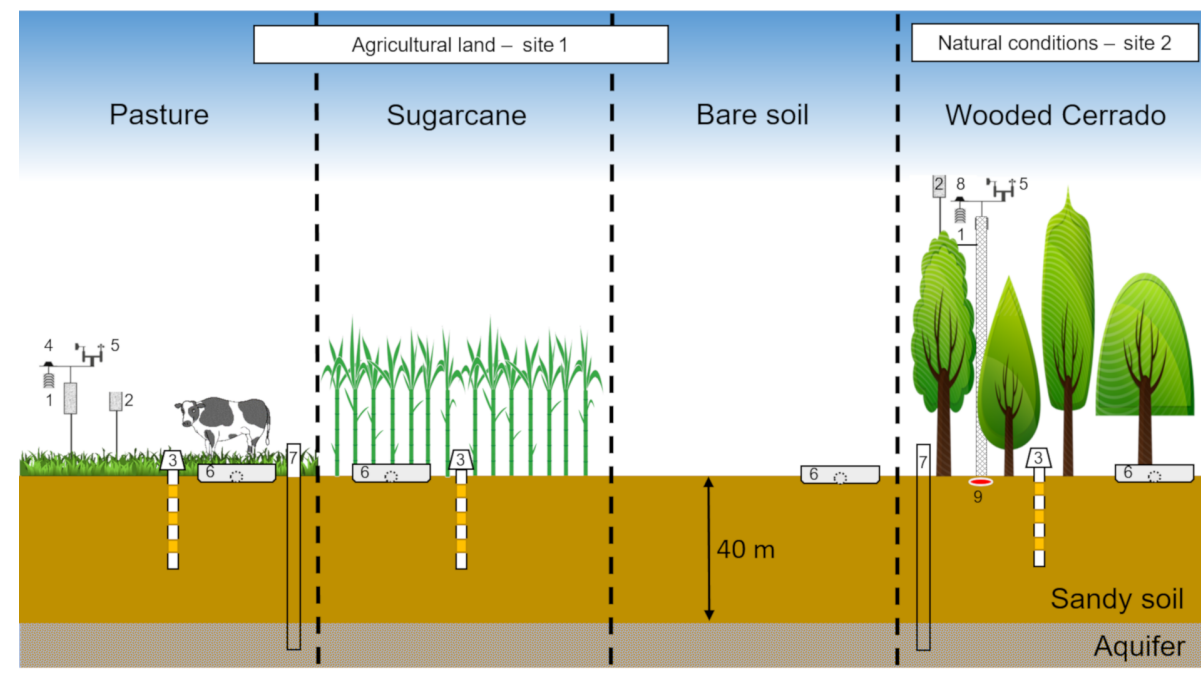

Figure 2. Hydrological monitoring performed on the four treatments: (1) relative humidity and air temperature probes at $2 \mathrm{~m}$ (site 1 ) and $11 \mathrm{~m}$ (site 2), (2) rainfall gauges, (3) soil moisture sensors, (4) solar radiation sensor, (5) wind speed and direction (anemometers) at $2 \mathrm{~m}$ (site 1 ) and at $11 \mathrm{~m}$ (site 2), (6) surface runoff collectors, (7) monitoring wells equipped with water table pressure transducers, (8) net radiation sensor, and (9) soil heat flux plate.

Table 1. Monitoring site instrumentation characteristics.

\begin{tabular}{|c|c|c|c|c|c|}
\hline Variable & Sensor & Height or depth (m) & Measurement range & Maximum error & Site no. \\
\hline \multirow{2}{*}{$\begin{array}{l}\text { Temperature }\left({ }^{\circ} \mathrm{C}\right) \text { and } \\
\text { relative humidity }(\%)\end{array}$} & HMP45C & 2.0 & \multirow{2}{*}{$\begin{array}{l}-39.2 \text { to }+60^{\circ} \mathrm{C} \text { and } \\
0.8 \% \text { to } 100 \%\end{array}$} & $\pm 0.5^{\circ} \mathrm{C}$ and $\pm 3 \%$ & 1 \\
\hline & $\mathrm{HC} 2 \mathrm{~S} 3$ & 9.5 and 11.0 & & $\pm 0.1^{\circ} \mathrm{C}$ and $\pm 0.8 \%$ & 2 \\
\hline Rainfall (mm) & Hydrological Services TB4 & 1.5 and 11.0 & 0 to $700 \mathrm{~mm} \mathrm{~h}^{-1}$ & $\pm 3 \%$ & 1 and 2 \\
\hline $\begin{array}{l}\text { Atmospheric pressure } \\
\text { (mbar) }\end{array}$ & Vaisala CS106 & 1.0 & 500 to 1100 mbar & $\pm 1.5 \mathrm{mbar}$ & 1 \\
\hline $\begin{array}{l}\text { Wind direction }\left(^{\circ}\right) \text { and } \\
\text { velocity }\left(\mathrm{m} \mathrm{s}^{-1}\right)\end{array}$ & Young 05103 & 2.0 and 11.0 & $\begin{array}{l}0 \text { to } 360^{\circ} \text { and } \\
0 \text { to } 100 \mathrm{~m} \mathrm{~s}^{-1}\end{array}$ & $\begin{array}{l} \pm 3^{\circ} \text { and } \\
\pm 0.3 \mathrm{~m} \mathrm{~s}^{-1}\end{array}$ & 1 and 2 \\
\hline Solar radiation $\left(\mathrm{MJ} \mathrm{m}^{-2}\right)$ & Kipp \& Zonen CMP3 & 2.0 & 0 to $2000 \mathrm{~W} \mathrm{~m}^{-2}$ & $\pm 5 \%$ & 1 \\
\hline \multirow[t]{2}{*}{ Soil moisture (\%) } & \multirow{2}{*}{ FDR EnviroSCAN Sentek } & $\begin{array}{l}-0.3 ; \\
-0.6 \text { and }-0.9 \\
\end{array}$ & \multirow[t]{2}{*}{0 to $\sim 65 \%$} & \multirow[t]{2}{*}{ $\pm 3 \%$} & $1^{*}$ \\
\hline & & $\begin{array}{l}-0.1 ;-0.5 ;-0.7 ; \\
-1.0 \text { and }-1.5\end{array}$ & & & 2 \\
\hline $\begin{array}{l}\text { Net solar radiation } \\
\left(\mathrm{W} \mathrm{m}^{-2}\right)\end{array}$ & Kipp \& Zonen NR-LITE2 & 11.0 & $\pm 2000 \mathrm{~W} \mathrm{~m}^{-2}$ & $\pm 5 \%$ & 2 \\
\hline Soil heat flux $\left(\mathrm{W} \mathrm{m}^{-2}\right)$ & Hukseflux HFP01 & -0.1 & $\pm 2000 \mathrm{~W} \mathrm{~m}^{-2}$ & $-15 \%$ to $+5 \%$ & 2 \\
\hline Groundwater table (m) & Diver Schlumberger & -40.0 and -39.2 & 0 to $10 \mathrm{~m}$ & $\pm 2.5 \mathrm{~cm}$ & 1 and 2 \\
\hline
\end{tabular}

* At site 1, the bare soil did not have soil moisture probes.

sented by the following equation:

$\frac{\mathrm{d} S}{\mathrm{~d} t}=P-O_{\mathrm{F}}-E_{\mathrm{T}}$,

where $P$ is the rainfall $(\mathrm{mm}) ; O_{\mathrm{F}}$ is the surface runoff $(\mathrm{mm})$; $E_{\mathrm{T}}$ is the evapotranspiration $(\mathrm{mm})$; and $\mathrm{d} S / \mathrm{d} t$ includes the soil water storage, subsurface flow and deep percolation $(\mathrm{mm})$ during time $t$ (day, month or year).

The rainfall was monitored using a tipping bucket (Model TB4, Hydrological Services) with a gauging resolution of $0.254 \mathrm{~mm}$ (Table 1). The rainfall data were registered every $10 \mathrm{~min}$ in order to obtain rainfall intensity and duration. 
Rectangular experimental plots directed the overland flow to tanks at the end of the slope, where the volume was measured at times after rainfall events. We also calculated the runoff coefficient for each LCLU using a genetic algorithm to minimize the squared errors between observed and estimated runoff values using the rational method (Wang, 1991).

The reference evapotranspiration $\left(E_{\mathrm{T}_{\mathrm{o}}}\right)$ was calculated on a daily basis using the Penman-Monteith equation parameterized by FAO 56 methodology (Allen et al., 1998). Afterwards, the evapotranspiration $\left(E_{\mathrm{T}}\right)$ values were obtained for pasture and sugarcane land uses using Eq. (2):

$E_{\mathrm{T}}=K_{\mathrm{S}} \cdot E_{\mathrm{T}_{\mathrm{c}}}=K_{\mathrm{S}} \cdot\left(K_{\mathrm{C}} \cdot E_{\mathrm{T}_{\mathrm{o}}}\right)$,

where $E_{\mathrm{T}}$ is the real evapotranspiration $\left(\mathrm{mm} \mathrm{d}^{-1}\right), K_{\mathrm{S}}$ is the water stress coefficient (dimensionless), $E_{\mathrm{Tc}}$ is the crop evapotranspiration $\left(\mathrm{mm} \mathrm{d}^{-1}\right), K_{\mathrm{C}}$ is the crop coefficient (dimensionless) and $E_{\mathrm{T}_{\mathrm{o}}}$ is the reference evapotranspiration ( $\mathrm{mm} \mathrm{d}^{-1}$; Eq. 3):

$$
E_{\mathrm{T}_{\mathrm{o}}}=\frac{0.408 \cdot \Delta \cdot\left(R_{\mathrm{n}}-G\right)+\frac{\gamma \cdot 900}{\left(T_{\mathrm{avg}}+273\right)} \cdot U_{2} \cdot\left(e_{\mathrm{s}}-e_{\mathrm{a}}\right)}{\Delta+\gamma \cdot\left(1+0.34 \cdot U_{2}\right)},
$$

where $s$ is the slope vapor pressure $\left(\mathrm{kPa}^{\circ} \mathrm{C}^{-1}\right), R_{\mathrm{n}}$ is the net radiation $\left(\mathrm{MJ} \mathrm{m}^{-2} \mathrm{~d}^{-1}\right), G$ is the soil heat flux $\left(\mathrm{MJ} \mathrm{m}^{-2} \mathrm{~d}^{-1}\right)$, $\gamma$ is the psychometric constant $\left(\mathrm{kPa}^{\circ} \mathrm{C}^{-1}\right), U_{2}$ is the wind velocity at $2 \mathrm{~m}$ height $\left(\mathrm{m} \mathrm{s}^{-1}\right), 900$ is the approximate value of all the equations' constants $\left(\mathrm{kJ}^{-1} \mathrm{~kg} \mathrm{~K} \mathrm{~d}^{-2}\right), T_{\text {avg }}$ is the average daily temperature $\left({ }^{\circ} \mathrm{C}\right), e_{\mathrm{S}}$ is the saturated vapor pressure $(\mathrm{kPa})$ and $e_{\mathrm{a}}$ is the actual vapor pressure $(\mathrm{kPa})$.

The water stress coefficient (Eq. 4) was calculated for each day $i$ throughout the monitoring period. It uses the soil moisture monitored by the frequency domain ratio (FDR) probes as the main input. When there is no water or limited water available for the plants' transpiration, $K_{\mathrm{S}}<1$. Whenever the soil has water readily available for plant consumption, $K_{\mathrm{S}}=1$. This is represented by

$K_{\mathrm{S}_{i}}=\frac{T_{\mathrm{AW}}-D_{\mathrm{r}_{i}}}{(1-p) \cdot T_{\mathrm{AW}}}$

where $T_{\mathrm{AW}}$ is the total available water in the soil root zone (mm; Eq. 5), $D_{\mathrm{r}_{i}}$ is the water depletion in the soil root zone (mm; Eq. 6) on day $i$ and $p$ is the $T_{\mathrm{AW}}$ fraction that the crop roots can extract from the soil without suffering from water stress (dimensionless). In addition,

$T_{\mathrm{AW}}=1000 \cdot\left(\theta_{\mathrm{fc}}-\theta_{\mathrm{wp}}\right) \cdot Z_{\mathrm{f}}$,

where $\theta_{\mathrm{fc}}$ is the soil field capacity (dimensionless), $\theta_{\mathrm{wp}}$ is the soil wilting point and $Z_{\mathrm{f}}$ is the root zone depth. Also,

$D_{\mathrm{r}_{i}}=1000 \cdot\left(\theta_{\mathrm{fc}}-\theta_{i}\right) \cdot Z_{\mathrm{f}}$,

where $\theta_{\mathrm{fc}}$ is the soil field capacity (dimensionless), $\theta_{i}$ is the average soil moisture along the root zone (measured by FDR probes) and $Z_{\mathrm{f}}$ is the root zone depth.
All the necessary data and coefficients for calculating the water stress coefficient $\left(K_{\mathrm{S}}\right)$ and the adjusted evapotranspiration rate $\left(E_{\mathrm{T}}\right)$ are given in Table 2 . It is worth mentioning that laboratory tests determined the soil field capacity and soil wilting point using Büchner funnels and Richards extraction chambers (Richards, 1931). The soil samples were collected with undisturbed structure in volumetric rings at depths of 20, 50 and $100 \mathrm{~cm}$.

The wooded Cerrado evapotranspiration $\left(E_{\mathrm{T}}\right)$ rates were estimated using the Priestley and Taylor (1972) method (Eq. 7). This method was chosen due to its simplicity to calculate the energy balance for the study area and due to the fact that it is suitable for the instrumentation available. The Priestley and Taylor coefficients $(\alpha)$ used to calculate the evapotranspiration were based on Cabral et al. (2015) measurements for a similar wooded Cerrado fragment located approximately $60 \mathrm{~km}$ away from the study site. The Priestley and Taylor coefficients $(\alpha)$ differed according to the season: 1.09 for Summer (December-March), 1.00 for Fall (MarchJune), 0.77 for Winter (June-September) and 0.98 for Spring (September-December). This method is represented by

$E_{\mathrm{T}}=\alpha \cdot\left(\frac{1}{\lambda}\right) \cdot\left[\frac{s \cdot\left(R_{\mathrm{n}}-G\right)}{s+\gamma}\right]$,

where $\alpha$ is the Priestley and Taylor coefficient (dimensionless), $\lambda$ is the latent heat of vaporization $\left(\mathrm{MJ} \mathrm{m}^{-2} \mathrm{~d}^{-1}\right), s$ is the slope vapor pressure $\left(\mathrm{kPa}^{\circ} \mathrm{C}^{-1}\right), R_{\mathrm{n}}$ is the net radiation $\left(\mathrm{MJ} \mathrm{m}^{-2} \mathrm{~d}^{-1}\right), G$ is the soil heat flux $\left(\mathrm{MJ} \mathrm{m}^{-2} \mathrm{~d}^{-1}\right)$ and $\gamma$ is the psychometric constant $\left(\mathrm{kPa}^{\circ} \mathrm{C}^{-1}\right)$.

The bare soil condition has no vegetation, and, consequently, there is no transpiration. Thus, we applied the method developed by Ritchie (1972). This method has two phases: firstly, the soil evaporation is equal to the potential soil evaporation estimated using the Priestley and Taylor (1972) method adapted to free surfaces. During this phase, there is no water restriction (precipitation higher than evaporation) and the evaporation is governed by the available energy; secondly, the accumulated soil evaporation exceeds the precipitation, and the soil evaporation is currently given as a function of the dry days that followed the last wet day. The evaporation cycle is interrupted and returns to the first phase whenever the precipitation exceeds the accumulated evaporation during the second phase.

\subsection{Groundwater table fluctuation}

The water table was registered twice a day (at 06:00 and 18:00 BRT - Brasilia Time) using pressure transducers (Diver, Schlumberger) placed inside two monitoring wells (well 1 is located in the pasture area, and well 2 is located inside the wooded Cerrado area). In the study site, both wells presented similar hydraulic conductivity according to the slug test (Bouwer and Rice, 1976) previously performed. We evaluated the aquifer hydraulic conductivity from both wells in order to validate the water table comparison among 
Table 2. Variables used to calculate evapotranspiration for sugarcane and pasture.

\begin{tabular}{|c|c|c|c|}
\hline Variable & Sugarcane & Pasture & Source \\
\hline$Z_{\mathrm{f}}(\mathrm{m})$ & $1.2-2.0$ & $0.5-1.5$ & \multirow{2}{*}{ Allen et al. (1998) } \\
\hline$p$ & 0.65 & 0.60 & \\
\hline$\theta_{\mathrm{fc}}$ & 0.14 & 0.14 & \multirow{2}{*}{$\begin{array}{l}\text { Values obtained from } \\
\text { laboratory essays (Oliveira, 2014) }\end{array}$} \\
\hline$\theta_{\mathrm{wp}}$ & 0.09 & 0.09 & \\
\hline$K_{\mathrm{C}}$ & $\begin{array}{l}\text { Plant (1): } \\
0.50^{\mathrm{a}}, 0.80^{\mathrm{b}}, 095^{\mathrm{c}}, 1.10^{\mathrm{d}}, 1.18^{\mathrm{e}}, 0.92^{\mathrm{f}}, 0.68^{\mathrm{g}} \\
\text { Ratoon }(2) \text { : } \\
0.55^{\mathrm{a}}, 0.80^{\mathrm{b}}, 090^{\mathrm{c}}, 1.00^{\mathrm{d}}, 1.05^{\mathrm{e}}, 0.80^{\mathrm{f}}, 0.60^{\mathrm{g}}\end{array}$ & $0.75(3)$ & $\begin{array}{l}\text { (1) Doorenbos et al. (1975) } \\
\text { (2) Doorenbos et al. (1979) } \\
\text { (3) Allen et al. (1998) }\end{array}$ \\
\hline
\end{tabular}

Approximate sugarcane age (days). $\left.{ }^{\mathrm{a}}(0-30) .{ }^{\mathrm{b}}(30-60) .{ }^{\mathrm{c}} 60-75\right) .{ }^{\mathrm{d}}(75-120) .{ }^{\mathrm{e}}(120-300) .{ }^{\mathrm{f}}(300-330) .{ }^{\mathrm{g}}(330-360)$.

each other, as if the aquifer condition in the wells were different, such comparison would not be fair. Both wells reach the water table at approximately $40 \mathrm{~m}$ depth in an unconfined sandstone formation (Botucatu Formation), which belongs to São Bento Group of the Mesozoic age. Furthermore, the soils above the aquifer that appears throughout the unsaturated zone are Cenozoic sediments weathered from the sandstone (Wendland et al., 2007). Additionally, despite the limited number of wells, the experimental design allowed a first look into the groundwater table behavior under different LCLU types (pasture and wooded Cerrado) and a crosscheck with the surface water balance outcomes.

\subsection{Data analysis}

The normality assumption was tested using the ShapiroWilk test considering a $95 \%$ confidence interval for rainfall, evapotranspiration, surface runoff and water balance residual datasets. The one-way analysis of variance (ANOVA) was applied to test the null and alternative hypothesis, that is, equality of surface runoff, evapotranspiration and water balance residual distribution functions between the four treatments (LCLU) versus the difference in distribution functions between at least two treatments. Additionally, the multiple comparisons between treatments were performed using the Tukey test (Montgomery, 2008). The rainfall, evapotranspiration, surface runoff, water balance residual and soil moisture graphs were plotted using a daily basis timescale. The groundwater table fluctuation was plotted using a monthly timescale due to the noise typically found in this kind of measurement. In order to present the order of magnitude over the years, the data were also resumed annually in tables and figures.

\subsection{Data uncertainties}

Data uncertainties are flaws found in the available information used to represent the reality and basically depend on the knowledge of the observed data (Refsgaard et al., 2007). The water balance uncertainty can be given by the standard error propagated from its components. Thus, the water balance residual $(\mathrm{d} S / \mathrm{d} t)$ standard error was propagated as follows:

$\sigma_{\mathrm{d} S}=\left(\sigma_{P}^{2}+\sigma_{O_{\mathrm{F}}}^{2}+\sigma_{E_{\mathrm{T}}}^{2}\right)^{0.5}$,

where $\sigma$ is the standard error $\left(\mathrm{mm} \mathrm{yr}^{-1}\right), \mathrm{d} S / \mathrm{d} t$ is the water balance residual, $P$ is rainfall, $O_{\mathrm{F}}$ is surface runoff and $E_{\mathrm{T}}$ is evapotranspiration.

The absolute error of the rainfall estimations was calculated using Eq. (9) based on the instrument accuracy informed by the manufacturer. Considering the used tipping bucket rain gauge (TB4), the error may reach up to $\pm 3 \%$. The equation is as follows:

$\sigma_{P}=\bar{P} \cdot \varepsilon_{P}$,

where $\sigma_{P}$ is the standard error for rainfall $\left(\mathrm{mm} \mathrm{yr}^{-1}\right), \bar{P}$ is the annual average rainfall $\left(\mathrm{mm} \mathrm{yr}^{-1}\right)$, and $\varepsilon_{P}$ is the relative error from the tipping bucket rain gauge informed by the manufacturer.

The surface runoff may vary due to the heterogeneities found between plots' replicates (Wendt et al., 1986; Nearing et al., 1999; Gómez et al., 2001; Sadeghi et al., 2013). Thus, the standard error for surface runoff is given by the standard deviation of the replicated plots:

$\sigma_{O_{\mathrm{F}}}=\left[\frac{1}{N-1} \sum_{i=1}^{\mathrm{N}}\left(O_{\mathrm{F}_{i}}-\bar{O}_{\mathrm{F}}\right)^{2}\right]^{0.5}$,

where $\sigma_{O_{\mathrm{F}}}$ is the standard error for surface runoff $\left(\mathrm{mm} \mathrm{yr}^{-1}\right)$, $N$ is the number of observations, $O_{\mathrm{F}_{i}}$ is the surface runoff observed in plot $i\left(\mathrm{~mm} \mathrm{yr}^{-1}\right)$ and $\bar{O}_{\mathrm{F}}$ is the average surface runoff between plots $\left(\mathrm{mm} \mathrm{yr}^{-1}\right)$.

As previously mentioned, the evapotranspiration was estimated using the FAO 56 methodology (Allen et al., 1998) for pasture and sugarcane and the Priestley and Taylor (1972) method for wooded Cerrado and bare soil. However, this 

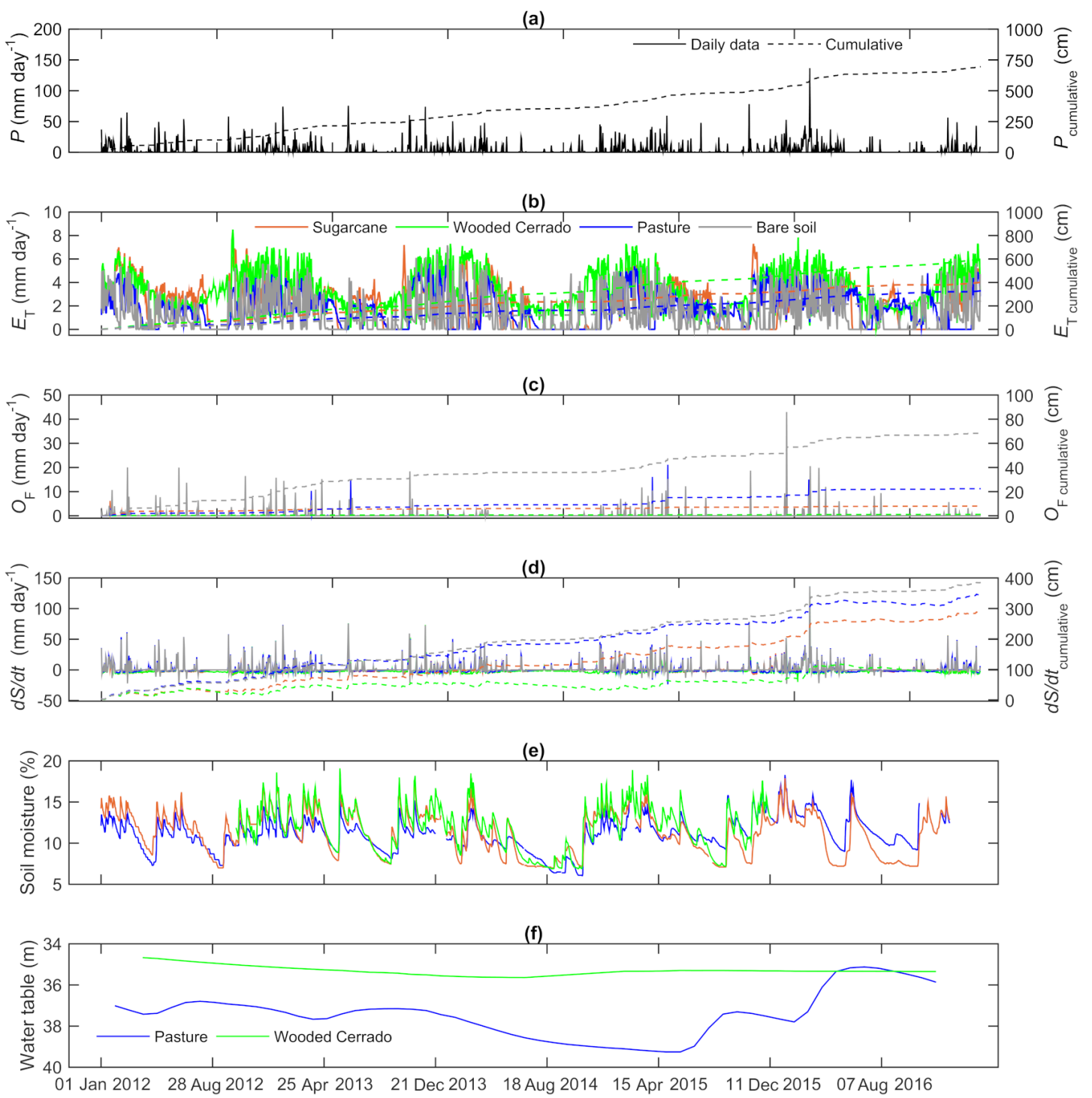

Figure 3. Water balance components for different LCLU types, namely rainfall, $P$ (a); evapotranspiration, $E_{\mathrm{T}}(\mathbf{b})$; surface runoff, $O_{\mathrm{F}}$ (c); and water balance residual, $\mathrm{d} S / \mathrm{d} t$ (d). Right axes present the cumulative sum of the variables represented by graphs (a), (b), (c) and (d). Soil moisture in the first meter of soil (e) for pasture, sugarcane and wooded Cerrado; water table (f) depth of the monitoring wells located in site 1 (pasture) and site 2 (wooded Cerrado).

study does not have evapotranspiration observations to evaluate how well this variable was estimated in the study sites. Consequently, the uncertainties for evapotranspiration estimates were calculated by combining all input variable uncertainties (Eq. 11) which were measured in the field for the FAO 56 method (temperature, relative humidity, solar radiation, barometric pressure and soil moisture) and the Priestley and Taylor method (temperature, net radiation and soil heat flux). The equation is as follows:

$\sigma_{E_{\mathrm{T}}}=\left[\sum_{i=1}^{N}\left(\frac{\partial_{\mathrm{var}_{i}}}{\partial_{E_{\mathrm{T}}}} \cdot u_{\mathrm{var}_{i}}\right)^{2}\right]^{0.5}$, where $\sigma_{E_{\mathrm{T}}}$ is the standard error for evapotranspiration $\left(\mathrm{mm} \mathrm{d}^{-1}\right)$, var ${ }_{i}$ is the measured input variable $i$ and $u$ is the uncertainty of variable $i$.

\section{Results and discussion}

\subsection{Water balance}

The water balance components show different patterns according to the LCLU (Table 3 and Fig. 3). We verified this using a multiple comparison test (Tukey) in which the water balance residual variation $(\mathrm{d} S / \mathrm{d} t)$ in the wooded Cerrado was statistically different from the other LCLU types 
(pasture, sugarcane and bare soil), which presented similar means. The annual evapotranspiration in the wooded Cerrado was the highest among the analyzed LCLU types. The pasture presented similar annual evapotranspiration values to those found in the sugarcane and bare soil. However, sugarcane and bare soil had different means for evapotranspiration among them. Concerning the surface runoff, bare soil and pasture presented significant differences from the other LCLU types. Hence, the results agree with previous studies, where the land use presented regulatory functions in the water balance (Krishnaswamy et al., 2013; Nobrega et al., 2017). Daily data of the water balance components and average soil moisture (first meter of soil) from the analyzed LCLU types are available in the Supplement (S1).

The average annual rainfall in the study site was $1388 \mathrm{~mm} \mathrm{yr}^{-1}$ between 2012 and 2016 (Fig. 3a). It was approximately $100 \mathrm{~mm} \mathrm{yr}^{-1}$ lower than the average observed during the last 37 years (Cabrera et al., 2016) due to a drought in 2014 (Getirana, 2015; Melo et al., 2016). Additionally, precipitation $(P)$ and the water balance residual $(\mathrm{d} S / \mathrm{d} t)$ were the water balance components that had the largest variations throughout the monitoring period. We observed that sugarcane and pasture were similar when considering the water balance components' patterns and orders of magnitude. However, wooded Cerrado and bare soil presented different characteristics from the other LCLU types.

The evapotranspiration estimates (Fig. 3b) were different between the considered land covers (Table 3). We observed that the wooded Cerrado evapotranspiration presented the highest rates among all analyzed LCLU types and also the smallest variability throughout the year. However, there is no agreement between the measurements and estimates performed in wooded Cerrado areas and the present study (Table 4), due to the diverse rainfall patterns among the study sites and the different methods used to measure or estimate the evapotranspiration. Thus, this study shows evidence of the need for reference values of evapotranspiration in undisturbed areas for a better understanding of their role in the water cycle. In addition, the rainfall is different for the studies compared in Table 4.

The sugarcane evapotranspiration rates were higher than pasture due to the higher crop water demand during the initial phase of its annual cycle, and both evapotranspiration estimates agree with measurements performed by previous studies (Sakai et al., 2004; Cabral et al., 2012; Nobrega et al., 2017). Both sugarcane and pastureland ceased the evapotranspiration during the dry season due to the decoupling condition, when the radiation is the only contributor to the evapotranspiration process (water stress condition; Pereira, 2004). This happens due to the lack of water readily available for the plants along the root zone. This condition does not repeat in the wooded Cerrado, as its root system is deeper (Canadell et al., 1996), and the plants may reach water in depths where sugarcane and pasture cannot do this. However, the root zone depth of undisturbed vegetation such as the wooded Cerrado is uncertain and may vary according to the soil characteristics (Canadell et al., 1996) and the groundwater table level (Leite et al., 2018). It may influence the plants' transpiration (Rawitscher, 1948; Oliveira et al., 2005) and, consequently, the water balance residual.

The surface runoff (Fig. 3c) presented the lowest values among all water balance components, and it was the most influenced variable by the land use. There was no surface runoff generation during August due to the non-occurrence of rainfall events. The bare soil was the most sensitive to the runoff generation throughout the dry season, when the occurrence of rainfall events was lower. The months of January, February and March registered the highest averages for rainfall due to the wet season. The runoff coefficients for wooded Cerrado, sugarcane, pasture and bare soil were $0.001,0.007,0.029$ and 0.063 , respectively. These values are in compliance with a previous study performed by Oliveira et al. (2016) for similar conditions. Although a higher runoff coefficient was expected for sugarcane in comparison with the pasture, sugarcane presented runoff values significantly lower than pasture as the soil tillage increased water infiltration and, consequently, reduced the surface runoff. Additionally, there is an apparent inverse linear relationship between culture size and runoff coefficient.

The surface runoff in sugarcane plantations is not well understood by the scientific community despite the economic importance to the country. The monitored values agreed with previous studies in the same study area (Oliveira et al., 2016; Youlton et al., 2016b; Anache et al., 2018). The highest runoff rates were registered after planting and harvesting events, when the soil is more exposed to the rainfall.

In addition, the surface runoff in the pasture presented significantly higher rates in comparison with sugarcane and wooded Cerrado, due to the top soil compaction caused by grazing. The order of magnitude of the measured runoff in the pasture plots is similar to that previously published (Saraiva et al., 1981; Silva et al., 2011; Dedecek, 1989). The high runoff variability observed in this land use was due to the variable presence of animals which were managed in an extensive approach, and, consequently, heterogeneities may happen in soil compaction and vegetation conditions (Nacinovic et al., 2014). Additionally, the deforestation and agricultural land uses may increase soil compaction, as the LCLUC influences the hydrological patterns along the soil profile by evident modifications in the soil characteristics (bulk density, infiltration capacity, etc.; Lamparter et al., 2016; Meister et al., 2017; de Almeida et al., 2018).

The wooded Cerrado presented the lowest runoff rates among all LCLU types due to the higher soil protection, which avoided the overland flow generation. The order of magnitude of the surface runoff in the wooded Cerrado was similar to those found in shrublands and forested areas (Dedecek, 1989; Silva et al., 2011; Oliveira, 2012, 2015; Nacinovic et al., 2014). These reduced surface runoff rates in the wooded Cerrado increase soil water infiltration in compari- 
Table 3. Mean and standard deviation of the annual water balance components for 2012-2016 period.

\begin{tabular}{|c|c|c|c|c|}
\hline \multirow[t]{2}{*}{ Land use } & \multicolumn{4}{|c|}{ Water balance components $\left(\mathrm{mm} \mathrm{yr}^{-1}\right)$} \\
\hline & $P$ & $\mathrm{~d} S / \mathrm{d} t$ & $E_{\mathrm{T}}$ & $O_{\mathrm{F}}$ \\
\hline Wooded Cerrado & \multirow{4}{*}{$1388 \pm 188$} & $185 \pm 182^{b}$ & $1201 \pm 49^{\mathrm{a}}$ & $2 \pm 2 c$ \\
\hline Pasture & & $689 \pm 135^{\mathrm{a}}$ & $654 \pm 137^{b c}$ & $45 \pm 26^{b}$ \\
\hline Sugarcane & & $571 \pm 100^{\mathrm{a}}$ & $801 \pm 212^{b}$ & $16 \pm 18^{\mathrm{c}}$ \\
\hline Bare soil & & $769 \pm 96^{\mathrm{a}}$ & $482 \pm 40^{\mathrm{c}}$ & $137 \pm 62^{\mathrm{a}}$ \\
\hline Data source & Observations & Residuals & Estimations & Observations \\
\hline
\end{tabular}

Table 4. Evapotranspiration and rainfall from studies developed in Brazil under similar LCLU to the present study.

\begin{tabular}{|c|c|c|c|c|c|c|}
\hline \multirow[t]{2}{*}{ Land use } & \multirow[t]{2}{*}{ Lat } & \multirow[t]{2}{*}{ Long } & \multirow[t]{2}{*}{ Method } & $E_{\mathrm{T}}$ & $P$ & \multirow[t]{2}{*}{ References } \\
\hline & & & & \multicolumn{2}{|c|}{$\left(\mathrm{mm} \mathrm{yr}^{-1}\right)$} & \\
\hline Sugarcane $^{1}$ & -21.63 & -47.78 & $\mathrm{EC}$ & 892 & 1194 & Cabral et al. (2012) \\
\hline Sugarcane $^{2}$ & -21.63 & -47.78 & $\mathrm{EC}$ & 685 & 1353 & Cabral et al. (2012) \\
\hline Sugarcane $^{1}$ & -22.18 & -47.85 & FAO 56 & 930 & 1535 & Present study \\
\hline Sugarcane $^{2}$ & -22.18 & -47.85 & FAO 56 & 715 & 1290 & Present study \\
\hline Wooded Cerrado & -21.62 & -47.65 & $\mathrm{EC}$ & 811 & 1498 & da Rocha et al. (2009) \\
\hline Wooded Cerrado & -21.62 & -47.65 & $\mathrm{EC}$ & 1228 & 1448 & Cabral et al. (2015) \\
\hline Wooded Cerrado & -15.93 & -47.88 & $\mathrm{EC}$ & 821 & 1440 & Giambelluca et al. (2009) \\
\hline Wooded Cerrado & -15.80 & -55.33 & PM RS & 1004 & 1696 & Nobrega et al. (2017) \\
\hline Wooded Cerrado & -22.18 & -47.85 & PM RS & 823 & 1194 & Oliveira et al. (2015) \\
\hline Wooded Cerrado & -22.18 & -47.85 & PT & 1201 & 1388 & Present study \\
\hline Pasture & -3.01 & -54.53 & $\mathrm{EC}$ & 647 & 1597 & Sakai et al. (2004) \\
\hline Pasture & -15.81 & -55.34 & PM RS & 639 & 1780 & Nobrega et al. (2017) \\
\hline Pasture & -22.18 & -47.85 & FAO 56 & 654 & 1388 & Present study \\
\hline Cerrado and Amazon transition & -11.41 & -55.33 & $\mathrm{EC}$ & 1005 & 2000 & Vourlitis et al. (2002) \\
\hline
\end{tabular}

Lat: latitude. Long: longitude. $E_{\mathrm{T}}$ : evapotranspiration. $P$ : rainfall. EC: eddy covariance. PM RS: Penman-Monteith and remote sensing. FAO 56: Allen et al. (1998). PT: Priestley and Taylor (1972). ${ }^{1}$ Plant. ${ }^{2}$ Ratoon.

son with pasture, sugarcane and bare soil. Thus, higher infiltration rates increase plant water availability (Krishnaswamy et al., 2013). Additionally, the organic matter layer above the soil (wooded Cerrado's forest floor litter) reduces the overland flow. In some cases, the litter removal may increase the surface runoff up to $50 \%$ (Gomyo and Kuraji, 2016).

The water balance residuals (Fig. 3d) showed the water surplus (positive values) and deficits (negative values), evidencing the consumption of the soil water storage in the dry season (June-September). Such behavior is also evidenced by the average soil water content along the first meter of soil (Fig. 3e), as the soil moisture became lower in the wooded Cerrado in comparison with pasture and sugarcane observations during the dry season. This is because only the wooded Cerrado condition had negative values during the dry season, as the other land uses (sugarcane and pasture) had no conditions to remove water from deeper regions due to the shallow root system and their physiological characteristics. Thus, wooded Cerrado vegetation adapted to dry weather conditions due to the plant water demand for evapotranspiration, which reduced gradually as long as the water balance residual accumulated during the wet season was consumed (Oishi et al., 2010; Christoffersen et al., 2014; Cabral et al., 2015; Oliveira et al., 2015). In addition, the structural quality of soil from undisturbed woodlands leads to a higher capacity for retaining water than that of pasture soil (Tseng et al., 2018).

\subsection{Groundwater table fluctuation}

The groundwater table fluctuation inside the wooded Cerrado area was lower compared to the pasture area considering the observations of the monitoring wells (Fig. 3f). This variation in the wooded Cerrado was less than $1 \mathrm{~m} \mathrm{yr}^{-1}$ due to the water deficit periods during the dry season. In addition, a similar study in a Cerrado area (Villalobos-Vega et al., 2014) verified that the groundwater table fluctuation tend to be lower where the unsaturated zone is thicker. In the well 
Table 5. Water balance uncertainties.

\begin{tabular}{|c|c|c|c|c|c|}
\hline \multirow[t]{2}{*}{ Variables } & & \multicolumn{4}{|c|}{ LCLU } \\
\hline & & Wooded Cerrado & Pasture & Sugarcane & Bare soil \\
\hline \multirow[t]{3}{*}{$P$ (observed) } & Average $\left(\mathrm{mm} \mathrm{yr}^{-1}\right)$ & \multicolumn{4}{|c|}{1388} \\
\hline & Standard error $\left(\sigma ; \mathrm{mm} \mathrm{yr}^{-1}\right)$ & \multicolumn{4}{|c|}{42} \\
\hline & Relative error $(\varepsilon ; \%)$ & \multicolumn{4}{|c|}{$3 \%$} \\
\hline \multirow[t]{3}{*}{$O_{\mathrm{F}}($ observed $)$} & Average $\left(\mathrm{mm} \mathrm{yr}^{-1}\right)$ & 2 & 45 & 16 & 137 \\
\hline & Standard error $\left(\sigma ; \mathrm{mm} \mathrm{yr}^{-1}\right)$ & 0.2 & 12 & 1 & 27 \\
\hline & Relative error $(\varepsilon ; \%)$ & $10 \%$ & $26 \%$ & $5 \%$ & $19 \%$ \\
\hline \multirow[t]{3}{*}{$E_{\mathrm{T}}($ estimated $)$} & Average $\left(\mathrm{mm} \mathrm{yr}^{-1}\right)$ & 1201 & 654 & 801 & 482 \\
\hline & Standard error $\left(\sigma ; \mathrm{mm} \mathrm{yr}^{-1}\right)$ & 634 & 412 & 361 & 39 \\
\hline & Relative error $(\varepsilon ; \%)$ & $53 \%$ & $63 \%$ & $45 \%$ & $8 \%$ \\
\hline \multirow[t]{3}{*}{$\mathrm{d} S / \mathrm{d} t$ (residual) } & Average $\left(\mathrm{mm} \mathrm{yr}^{-1}\right)$ & 185 & 689 & 571 & 769 \\
\hline & Standard error $\left(\sigma ; \mathrm{mm} \mathrm{yr}^{-1}\right)$ & 636 & 415 & 363 & 63 \\
\hline & Relative error $(\varepsilon ; \%)$ & $344 \%$ & $60 \%$ & $64 \%$ & $8 \%$ \\
\hline
\end{tabular}

$\mathrm{d} S / \mathrm{d} t$ : water balance residual. $P$ : precipitation. $E_{\mathrm{T}}$ : evapotranspiration. $O_{\mathrm{F}}$ : surface runoff.

located in the pasture, the water table fluctuated negatively in 2014 and 2015 due to the drought that happened in 2014 (Getirana, 2015). The water surplus of 2015-2016 happened due to the La Niña phenomena, which raised the rainfall pattern after the long dry season of 2014-2015 (Kakatkar et al., 2018). Consequently, the water table was raised in 2016. The water scarcity periods that occurred in the wooded Cerrado area were due to the higher vegetation demand, as it is denser than the pasture and has a deep root system. It is important to remember that both monitoring wells (pasture and wooded Cerrado) have the same non-saturated zone thickness ( $40 \mathrm{~m}$ ) and similar hydraulic characteristics. However, in order to perform more complete evaluations of the hydrogeological processes in the study site, further measurements and additional monitoring wells may be necessary.

There is clear evidence that a time lapse between the water infiltration through the soil and the aquifer recharge exists due to the huge non-saturated zone thickness (around $40 \mathrm{~m}$; Fig. 3f). For this reason, we cannot ignore that the evapotranspiration influences the aquifer recharge, as previously reported by other studies under conditions similar to and different from the present study (Scanlon et al., 2005; Scott et al., 2014; Lucas et al., 2015; Oliveira et al., 2017; Lucas and Wendland, 2015). Changes in the LCLU, such as the potential conversion from wooded Cerrado to an agricultural LCLU (here we tested the pasture), may affect groundwater recharge, processes and availability. These effects tend to be non-linear and difficult to analyze as they result from complex interactions between LCLU and hydrological processes (Han et al., 2017). Thus, mathematical approaches (Archer and Fowler, 2018; Gómez et al., 2018) or natural tracers (Su et al., 2018) are useful tools for verifying the response time of the groundwater table to the water balance from different
LCLU types. In further studies, such techniques may be part of a solution for investigating how responsive the aquifer is to the surface water partitioning in the conditions considered here over time.

The evapotranspiration and root zone depth controlled the water balance residual and, consequently, the water percolation throughout the non-saturated zone and aquifer recharge (Finch, 1998; Gouvêa and Wendland, 2011; Krishnaswamy et al., 2013; Lucas and Wendland, 2015; Domínguez et al., 2016; Manzione et al., 2017). In the pasture area (site 1), the soil water that was not consumed by the plants did not evaporate, flowing down along the unsaturated zone. Consequently, the water uptake by the plants became unfeasible, as the roots were more shallow (see Table 2) than in the wooded Cerrado. Furthermore, the aquifer recharge decreases as the vegetation density increases in undisturbed Cerrado areas (Oliveira et al., 2017), following the principle that the increased canopy cover of the wooded Cerrado found in the study area may occur due to the deep groundwater level (Leite et al., 2018; Villalobos-Vega et al., 2014). However, the water balance analysis performed here focused on hillslope hydrology, and the monitoring well depths reflect the aquifer behavior in a broader area covered by pasture and wooded Cerrado in comparison with the $100 \mathrm{~m}^{2}$ plots where we monitored the surface water partitioning. Thus, all assumptions made throughout this section are subject to further analysis, which may include the water balance calculation for a broader area (e.g., the whole 300 ha wooded Cerrado fragment where part of the present study plots were located to represent either LCLU). Nevertheless, the hillslope-scale water balance outcomes are comparable to the groundwater table fluctuations, as the wells represent the plots' surroundings for the pasture and wooded Cerrado LCLU. Groundwa- 


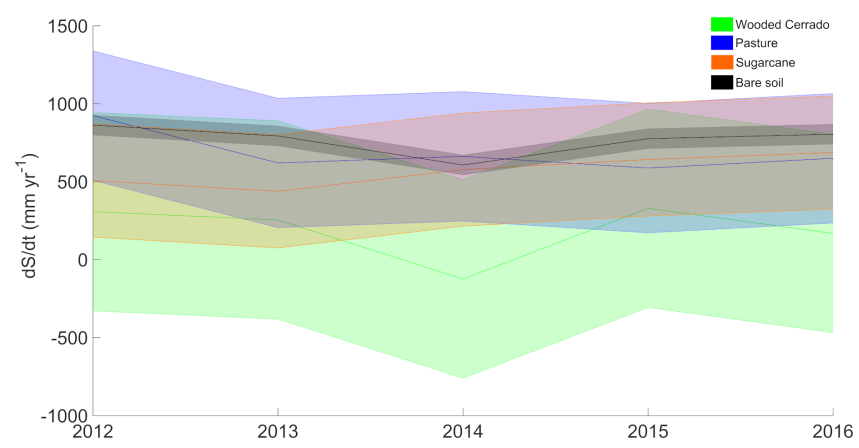

Figure 4. Annual water balance residual $(\mathrm{d} S / \mathrm{d} t)$ for different LCLU types during 2012-2016 period; shaded areas indicate the standard error (uncertainties) of $\mathrm{d} S / \mathrm{d} t$ estimates.

ter depth monthly datasets of the monitoring wells (wooded Cerrado and pasture) are available in the Supplement (S2).

\subsection{Data uncertainties}

The water balance component $\left(P, O_{\mathrm{F}}, E_{\mathrm{T}}\right.$ and $\left.\mathrm{d} S / \mathrm{d} t\right)$ uncertainties were calculated for each land cover (Table 5), and the relative errors agreed with previous water balance studies on different scales (Graham et al., 2010; Oliveira et al., 2014). Concerning rainfall $(P)$, which is the only water input, the same measured values were used for all LCLU types. The surface runoff presented higher relative uncertainties in the pasture plots, followed by bare soil, wooded Cerrado and, later, sugarcane. Evapotranspiration $\left(E_{\mathrm{T}}\right)$ can be a potential source of uncertainties in a water balance (da Paz et al., 2014); it was estimated adopting methods that use ground-measured variables (e.g., temperature, relative humidity, solar radiation and soil moisture), and the relative uncertainties may reach up to $63 \%$. The pasture presented the higher relative error for $E_{\mathrm{T}}$ due to the reduced average evapotranspiration compared to the other LCLU types (sugarcane and wooded Cerrado), and the wooded Cerrado presented the higher standard error for $E_{\mathrm{T}}$. Nevertheless, the water balance hypothesis mainly relies on minimizing uncertainties in the evapotranspiration estimates or measurements (Beven, 2006). The surface runoff $\left(O_{\mathrm{F}}\right)$ did not contribute significantly to the water balance error propagation due to its reduced order of magnitude compared to the other water balance components $\left(E_{\mathrm{T}}\right.$ and $\left.P\right)$. However, runoff measurements produced relative errors that reached up to $26 \%$ (pasture).

The water balance residual $(\mathrm{d} S / \mathrm{d} t)$ presented the accumulated uncertainties from rainfall, surface runoff and evapotranspiration (Fig. 4). All LCLU types presented standard errors for $\mathrm{d} S / \mathrm{d} t$ with similar orders of magnitudes, except the bare soil, which presented lower errors due to the reduced number of inputs for calculating the evaporation in an opensurface condition. The wooded Cerrado accumulated an error of $636 \mathrm{~mm} \mathrm{yr}^{-1}$ for the water balance residual, mainly due to its highest component, evapotranspiration. This suggests that efforts to minimize the uncertainties in measuring or estimating the evapotranspiration in the wooded Cerrado may significantly improve its water balance. Additionally, other land uses (pasture and sugarcane) also presented a high $\mathrm{d} S / \mathrm{d} t$ uncertainty due to the standard error accumulated from the evapotranspiration estimates.

\subsection{Water balance trade-offs due to the LCLUC}

The Brazilian Cerrado is very important economically, as it is responsible for most of the agricultural production that supplies both external and internal markets (Klink and Machado, 2005). A better understanding of the trade-offs between the ecosystem and economical needs that govern the land cover and land use dynamics in the Cerrado biome is necessary (Marris, 2005). The undisturbed Cerrado area was reduced to $50 \%$ of its original extension due to intense land use (Lapola et al., 2013; Alkimim et al., 2015). The undisturbed vegetation helps in maintaining the water cycle, with low surface runoff and high evapotranspiration rates.

This study shows evidence that the suppression of the wooded Cerrado and the conversion to agricultural land uses, such as sugarcane and pasture, increased the surface runoff and decreased evapotranspiration, even considering measurements and estimation method uncertainties. Consequently, the water balance residual $(\mathrm{d} S / \mathrm{d} t)$ increased significantly, suggesting that the infiltration also rose. However, the soil water was not as available to the plants' roots in the agricultural land uses during the dry season (April-September) as the wooded Cerrado, where the soil water content is (on average) higher than the agricultural LCLU (Fig. 3e). Thus, the percolation and aquifer recharge increased in the agricultural area (site 1), and this fact was explained by the water table fluctuations observed in the monitoring well located in the pasture that were not observed in the monitoring well located inside the wooded Cerrado area (site 2).

Previous studies show that native forests help in maintaining aquifer recharge by the high infiltration rates, similar to observations performed in tropical forests in southern India and in mountainous areas in the Himalayas $(\mathrm{Kr}-$ ishnaswamy et al., 2013; Ghimire et al., 2014). Nevertheless, evapotranspiration appears to be a key component in the aquifer recharge control in the study site condition, which is located in a Guarani aquifer system outcrop zone (Lucas et al., 2015; Lucas and Wendland, 2015). Therefore, the aquifer recharge rates, evidenced here by the groundwater table fluctuation (Fig. 3f), may be reduced in forested areas in comparison with agricultural landscapes due to the atmospheric and vegetation water demands and the increased soil water retention capacity (Adane et al., 2018; Dias et al., 2015; Wang et al., 2018; Tseng et al., 2018). This validates the information stating that the LCLU significantly impacts groundwater recharge (Scanlon et al., 2005; Scott et al., 2014; Lucas et al., 2015; Dawes et al., 2012). This fact may suggest that 


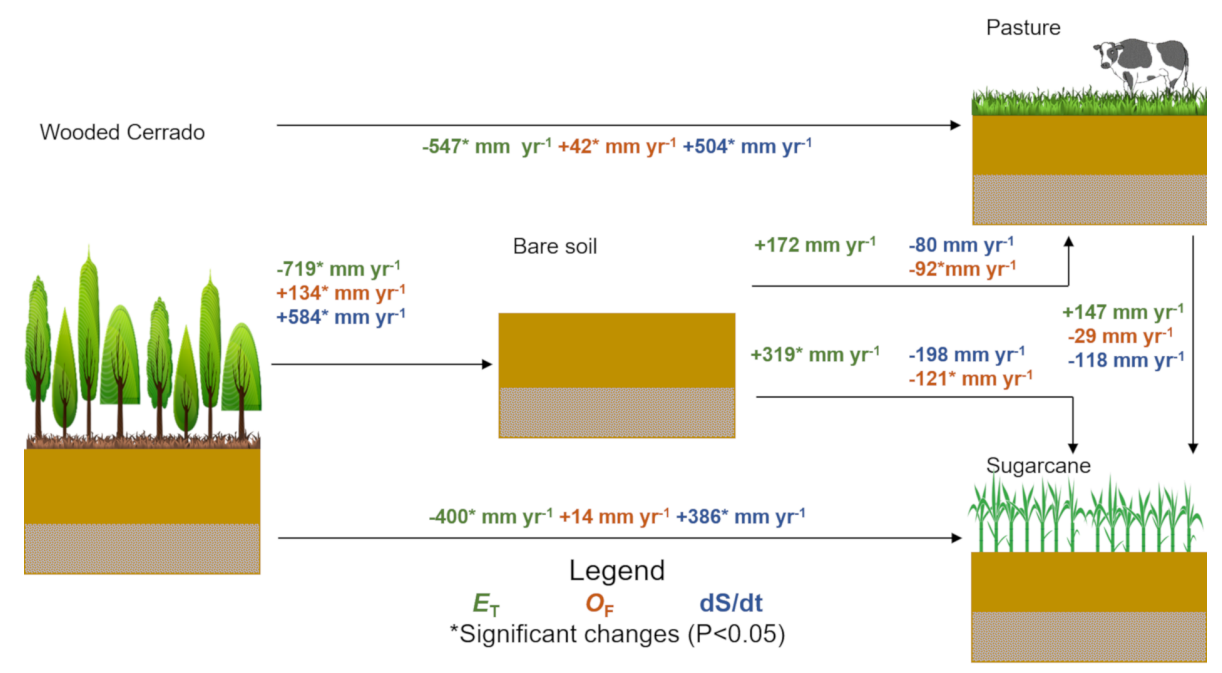

Figure 5. Annual observed means (2012-2016) of hydrological trade-offs related to evapotranspiration $\left(E_{\mathrm{T}}\right)$, surface runoff $\left(O_{\mathrm{F}}\right)$ and water balance residual $(\mathrm{d} S / \mathrm{d} t)$ due to potential LCLUC found in southeastern Brazil.

the ecosystem service of native forests, such as the wooded Cerrado, is not the aquifer recharge maintenance but rather the constant return of water to the atmosphere throughout the year.

Significant and non-significant changes in the water partitioning may be observed in the case of substituting the wooded Cerrado with bare soil, pasture or sugarcane (Fig. 5). We highlight the $E_{\mathrm{T}}$ reduction (more than $400 \mathrm{~mm} \mathrm{yr}^{-1}$ ). The worst-case scenario (bare soil condition) is generally the transition between the LCLU (fallow condition), which significantly increases surface runoff rates and impacts soil and water conservation (Pimentel et al., 1995).

Sugarcane and pasture presented trade-offs that were equal, as non-significant changes occurred among each other's water balance components. However, the sugarcane plantation presented a higher potential for maintaining the evapotranspiration rates that are closer to the undisturbed Cerrado conditions than the pasture, agreeing with previous estimates (Loarie et al., 2011). In addition, it is suggested that sugarcane has increased evapotranspiration rates in comparison with other annual crops (Guarenghi and Walter, 2016; Hernandes et al., 2018b, a).

\section{Conclusions}

This paper presented an experimental approach at the hillslope scale, concerning the possible water partitioning tradeoffs due to the LCLUC dynamics. We monitored the water balance components over 5 years in different land covers: wooded Cerrado, pasture, sugarcane and bare soil. These land covers are subjected to the current LCLUC dynamics in southeastern Brazil. The water partitioning observations in different LCLU types confirm that modifications in the land surface conditions may significantly change the water bal- ance residual (up to $584 \mathrm{~mm} \mathrm{yr}^{-1}$ ). The decrease in evapotranspiration and increase in surface runoff are common patterns when the wooded Cerrado is replaced by agricultural land uses. The water balance outcomes evidence that the undisturbed Cerrado vegetation consumes the soil water storage in the dry season (June-September). In contrast, the agricultural LCLU (pasture and sugarcane) reduce or even stop the water consumption in either season. The probable main reason for that is the reduced water retention capacity commonly found in disturbed soils.

Higher water consumption by dense and native vegetation, such as the wooded Cerrado, also happens due to the higher infiltration rates, increasing the plant water availability. In general, the root systems are deeper than pasturelands and sugarcane plantations and have the capacity of reaching water for transpiration deeper in the soil profile. This maintains evapotranspiration throughout the year, even during the dry season. Hence, less water becomes available for the aquifer recharge in areas where the canopy layer is higher and denser. However, reference values for evapotranspiration in undisturbed land covers, such as the wooded Cerrado, are still needed in order to reduce uncertainties from the current approximations and validate the water balance hypothesis. Particularly the undisturbed Cerrado and the agricultural LCLU should be investigated concerning their potential for maintaining the aquifer recharge and groundwater availability as well as answering how responsive the aquifer is to the surface water partitioning in different LCLU types over time.

Data availability. The datasets underlying this research are available in the Supplement (S1 and S2) of this paper, and they are accessible from the following data repository link: http://www. hydroshare.org/resource/a1c032dbb78d48748b673c876c20b21c (Anache, 2019). 
Supplement. The supplement related to this article is available online at: https://doi.org/10.5194/hess-23-1263-2019-supplement.

Author contributions. JAAA, EW, PTSO and CY designed the experiments, and JAAA, LMPR, PTSO and CY carried them out. JAAA, LMPR and EW analyzed the experiments' outcomes and discussed the results. JAAA and EW prepared the paper with contributions from all co-authors.

Competing interests. The authors declare that they have no conflict of interest.

Acknowledgements. This study was supported by grants from the Ministry of Science, Technology, Innovation and Communication - MCTIC - and the National Council for Scientific and Technological Development - CNPq (grant numbers 201109/2015-8, 142393/2015-0, 150057/2018-0, 441289/2017-7, 306830/2017-5, and 302991/2017-4); the São Paulo Research Foundation FAPESP (grant number 2015/03806-1); and the Coordination of Improvement of Higher Education Personnel - CAPES (finance code 001). The authors acknowledge the graduate program in Hydraulics and Sanitary Engineering - PPGSHS (USP-EESC) for the scientific support and the Arruda Botelho Institute - IAB - for allowing the development of this study on its private land. The authors would like also to thank the editor and the anonymous referees for their useful comments, which substantially improved the paper.

Edited by: Martijn Westhoff

Reviewed by: three anonymous referees

\section{References}

Adane, Z. A., Nasta, P., Zlotnik, V., and Wedin, D.: Impact of grassland conversion to forest on groundwater recharge in the Nebraska Sand Hills, J. Hydrol., 15, 171-183, https://doi.org/10.1016/j.ejrh.2018.01.001, 2018.

Alberton, B., Almeida, J., Helm, R., da S. Torres, R., Menzel, A., and Morellato, L. P. C.: Using phenological cameras to track the green up in a cerrado savanna and its on-the-ground validation, Ecol. Inform., 19, 62-70, https://doi.org/10.1016/j.ecoinf.2013.12.011, 2014.

Alkimim, A., Sparovek, G., and Clarke, K. C.: Converting Brazil's pastures to cropland: An alternative way to meet sugarcane demand and to spare forestlands, Appl. Geogr., 62, 75-84, https://doi.org/10.1016/j.apgeog.2015.04.008, 2015.

Allen, R. G., Pereira, L. S., Raes, D., and Smith, M.: Crop evapotranspiration - Guidelines for computing crop water requirements - FAO Irrigation and drainage paper 56, FAO - Food and Agriculture Organization of the United Nations, Rome, 326 pp., 1998.

Alvares, C. A., Stape, J. L., Sentelhas, P. C., Gonçalves, J. L. M., and Sparovek, G.: Koppen's climate classification map for Brazil, Meteorol. Z., 22, https://doi.org/10.1127/0941-2948/2013/0507, 711-728, 2014.
Anache, J. A. A., Wendland, E. C., Oliveira, P. T. S., Flanagan, D. C., and Nearing, M. A.: Runoff and soil erosion plot-scale studies under natural rainfall: A metaanalysis of the Brazilian experience, Catena, 152, 29-39, https://doi.org/10.1016/j.catena.2017.01.003, 2017.

Anache, J. A. A., Flanagan, D. C., Srivastava, A., and Wendland, E. C.: Land use and climate change impacts on runoff and soil erosion at the hillslope scale in the Brazilian Cerrado, Sci. Total Environ., 622, 140 151, https://doi.org/10.1016/j.scitotenv.2017.11.257, 2018 Anache, J. A. A.: Supplement for: Hydrological tradeoffs due to different land covers and land uses in the Brazilian Cerrado, HydroShare, https://doi.org/10.4211/hs. a1c032dbb78d48748b673c876c20b21c, (last access: 7 December 2018), 2019.

Archer, D. R. and Fowler, H. J.: Characterising flash flood response to intense rainfall and impacts using historical information and gauged data in Britain, J. Flood Risk Manag., 11, 121-133, https://doi.org/10.1111/jfr3.12187, 2018.

Barretto, A. G., Berndes, G., Sparovek, G., and Wirsenius, S.: Agricultural intensification in Brazil and its effects on land-use patterns: an analysis of the 1975-2006 period, Global Change Biol., 19, 1804-1815, https://doi.org/10.1111/gcb.12174, 2013.

Bellezoni, R. A., Sharma, D., Villela, A. A., and Pereira Junior, A. O.: Water-energy-food nexus of sugarcane ethanol production in the state of Goiás, Brazil: An analysis with regional input-output matrix, Biomass Bioenerg., 115, 108-119, https://doi.org/10.1016/j.biombioe.2018.04.017, 2018.

Beuchle, R., Grecchi, R. C., Shimabukuro, Y. E., Seliger, R., Eva, H. D., Sano, E., and Achard, F.: Land cover changes in the Brazilian Cerrado and Caatinga biomes from 1990 to 2010 based on a systematic remote sensing sampling approach, Appl. Geogr., 58, 116-127, https://doi.org/10.1016/j.apgeog.2015.01.017, 2015.

Beven, K.: On undermining the science?, Hydrol. Process., 20, 3141-3146, https://doi.org/10.1002/hyp.6396, 2006.

Bonan, G. B.: Forests and climate change: forcings, feedbacks, and the climate benefits of forests, Science, 320, 1444-1449, https://doi.org/10.1126/science.1155121, 2008.

Bouwer, H. and Rice, R. C.: A slug test for determining hydraulic conductivity of unconfined aquifers with completely or partially penetrating wells, Water Resour. Res., 12, 423-428, https://doi.org/10.1029/WR012i003p00423, 1976.

Brannstrom, C., Jepson, W., Filippi, A. M., Redo, D., Xu, Z., and Ganesh, S.: Land change in the Brazilian Savanna (Cerrado), 1986-2002: Comparative analysis and implications for land-use policy, Land Use Policy, 25, 579-595, https://doi.org/10.1016/j.landusepol.2007.11.008, 2008.

Burt, T. P. and McDonnell, J. J.: Whither field hydrology?, The need for discovery science and outrageous hydrological hypotheses, Water Resour. Res., 51, 5919-5928, https://doi.org/10.1002/2014WR016839, 2015.

Cabral, O. M. R., Rocha, H. R., Gash, J. H., Ligo, M. A. V., Tatsch, J. D., Freitas, H. C., and Brasilio, E.: Water use in a sugarcane plantation, GCB Bioenergy, 4, 555-565, https://doi.org/10.1111/j.1757-1707.2011.01155.x, 2012.

Cabral, O. M. R., da Rocha, H. R., Gash, J. H., Freitas, H. C., and Ligo, M. A. V.: Water and energy fluxes from a woodland savanna (cerrado) in southeast Brazil, J. Hydrol., 4, 22-40, https://doi.org/10.1016/j.ejrh.2015.04.010, 2015. 
Cabrera, M. C. M., Anache, J. A. A., Youlton, C., and Wendland, E.: Performance of evaporation estimation methods compared with standard $20 \mathrm{~m}^{-2}$ tank, Rev. Bras. Eng. Agr. Amb., 20, 874879, https://doi.org/10.1590/1807-1929/agriambi.v20n10p874879, 2016.

Canadell, J., Jackson, R. B., Ehleringer, J. B., Mooney, H. A., Sala, O. E., and Schulze, E.-D.: Maximum rooting depth of vegetation types at the global scale, Oecologia, 108, 583-595, https://doi.org/10.1007/bf00329030, 1996.

Christoffersen, B. O., Restrepo-Coupe, N., Arain, M. A., Baker, I. T., Cestaro, B. P., Ciais, P., Fisher, J. B., Galbraith, D., Guan, X., Gulden, L., van den Hurk, B., Ichii, K., Imbuzeiro, H., Jain, A., Levine, N., Miguez-Macho, G., Poulter, B., Roberti, D. R., Sakaguchi, K., Sahoo, A., Schaefer, K., Shi, M., Verbeeck, H., Yang, Z.-L., Araújo, A. C., Kruijt, B., Manzi, A. O., da Rocha, H. R., von Randow, C., Muza, M. N., Borak, J., Costa, M. H., Gonçalves de Gonçalves, L. G., Zeng, X., and Saleska, S. R.: Mechanisms of water supply and vegetation demand govern the seasonality and magnitude of evapotranspiration in Amazonia and Cerrado, Agr. Forest Meteorol., 191, 3350, https://doi.org/10.1016/j.agrformet.2014.02.008, 2014.

da Paz, A. R., Collischonn, W., Bravo, J. M., Bates, P. D., and Baugh, C.: The influence of vertical water balance on modelling Pantanal (Brazil) spatio-temporal inundation dynamics, Hydrol. Process., 28, 3539-3553, https://doi.org/10.1002/hyp.9897, 2014.

da Rocha, H. R., Manzi, A. O., Cabral, O. M., Miller, S. D., Goulden, M. L., Saleska, S. R., R.-Coupe, N., Wofsy, S. C., Borma, L. S., Artaxo, P., Vourlitis, G., Nogueira, J. S., Cardoso, F. L., Nobre, A. D., Kruijt, B., Freitas, H. C., von Randow, C., Aguiar, R. G., and Maia, J. F.: Patterns of water and heat flux across a biome gradient from tropical forest to savanna in Brazil, J. Geophys. Res., 114, G00B12, https://doi.org/10.1029/2007jg000640, 2009.

Dawes, W., Ali, R., Varma, S., Emelyanova, I., Hodgson, G., and McFarlane, D.: Modelling the effects of climate and land cover change on groundwater recharge in south-west Western Australia, Hydrol. Earth Syst. Sci., 16, 2709-2722, https://doi.org/10.5194/hess-16-2709-2012, 2012.

de Almeida, W. S., Panachuki, E., de Oliveira, P. T. S., da Silva Menezes, R., Sobrinho, T. A., and de Carvalho, D. F.: Effect of soil tillage and vegetal cover on soil water infiltration, Soil Till. Res., 175, 130-138, https://doi.org/10.1016/j.still.2017.07.009, 2018.

Dedecek, R. A.: Coberturas permanentes do solo na erosão sob condições de cerrados, Pesqui. Agropecu. Bras., 24, 483-488, 1989.

Dias, L. C. P., Macedo, M. N., Costa, M. H., Coe, M. T., and Neill, C.: Effects of land cover change on evapotranspiration and streamflow of small catchments in the Upper Xingu River Basin, Central Brazil, J. Hydrol., 4, 108-122, https://doi.org/10.1016/j.ejrh.2015.05.010, 2015.

Domínguez, C. G., Pryet, A., García Vera, M., Gonzalez, A., Chaumont, C., Tournebize, J., Villacis, M., d'Ozouville, N., and Violette, S.: Comparison of deep percolation rates below contrasting land covers with a joint canopy and soil model, J. Hydrol., 532, 65-79, https://doi.org/10.1016/j.jhydrol.2015.11.022, 2016.
Doorenbos, J., Pruitt, W. O., Aboukhaled, A., Food, and Nations, A. O. o. t. U.: Guidelines for Predicting Crop Water Requirements, Food and Agriculture Organization of the United Nations, 1975.

Doorenbos, J., Kassam, A. H., and Bentvelsen, C. I. M.: Yield response to water, Food and Agriculture Organization of the United Nations, 1979.

Dotterweich, M.: The history of human-induced soil erosion: Geomorphic legacies, early descriptions and research, and the development of soil conservation - A global synopsis, Geomorphology, 201, 1-34, https://doi.org/10.1016/j.geomorph.2013.07.021, 2013.

Finch, J. W.: Estimating direct groundwater recharge using a simple water balance model - sensitivity to land surface parameters, J. Hydrol., 211, 112-125, https://doi.org/10.1016/S00221694(98)00225-X, 1998.

Frank, S., Fürst, C., Witt, A., Koschke, L., and Makeschin, F.: Making use of the ecosystem services concept in regional planning - trade-offs from reducing water erosion, Landscape Ecol., 29, 1377-1391, https://doi.org/10.1007/s10980-014-9992-3, 2014.

Garcia-Montiel, D. C., Coe, M. T., Cruz, M. P., Ferreira, J. N., da Silva, E. M., and Davidson, E. A.: Estimating seasonal changes in volumetric soil water content at landscape scales in a savanna ecosystem using two-dimensional resistivity profiling, Earth Interact., 12, 1-25, https://doi.org/10.1175/2007ei238.1, 2008.

Getirana, A. C. V.: Extreme water deficit in Brazil detected from space, J. Hydrometeorol., 17, 591-599, https://doi.org/10.1175/JHM-D-15-0096.1, 2015.

Ghimire, C. P., Bruijnzeel, L. A., Lubczynski, M. W., and Bonell, M.: Negative trade-off between changes in vegetation water use and infiltration recovery after reforesting degraded pasture land in the Nepalese Lesser Himalaya, Hydrol. Earth Syst. Sci., 18, 4933-4949, https://doi.org/10.5194/hess-18-4933-2014, 2014.

Giambelluca, T. W., Scholz, F. G., Bucci, S. J., Meinzer, F. C., Goldstein, G., Hoffmann, W. A., Franco, A. C., and Buchert, M. P.: Evapotranspiration and energy balance of Brazilian savannas with contrasting tree density, Agr. Forest Meteorol., 149, 13651376, https://doi.org/10.1016/j.agrformet.2009.03.006, 2009.

Gibbs, H. K., Ruesch, A. S., Achard, F., Clayton, M. K., Holmgren, P., Ramankutty, N., and Foley, J. A.: Tropical forests were the primary sources of new agricultural land in the 1980s and 1990s, P. Natl. Acad. Sci. USA, 107, 16732-16737, https://doi.org/10.1073/pnas.0910275107, 2010.

Gómez, D., Melo, D. C. D., Rodrigues, D. B. B., Xavier, A. C., Guido, R. C., and Wendland, E.: Aquifer Responses to Rainfall through Spectral and Correlation Analysis, J. Am. Water Resour. As., 54, 1341-1354, https://doi.org/10.1111/1752-1688.12696, 2018.

Gómez, J. A., Nearing, M. A., Giráldez, J. V., and Alberts, E. E.: Analysis of sources of variability of runoff volume in a 40 plot experiment using a numerical model, J. Hydrol., 248, 183-197, https://doi.org/10.1016/S0022-1694(01)00402-4, 2001.

Gomyo, M. and Kuraji, K.: Effect of the litter layer on runoff and evapotranspiration using the paired watershed method, J. Forest Res.-Jpn., 21, 306-313, https://doi.org/10.1007/s10310-0160542-5, 2016.

Gouvêa, T. H. and Wendland, E. C.: Influência de características do solo na variação do nível d água em região de recarga do Aquífero Guarani, Rev. Bras. Rec. Hid., 16, 55-65, 2011. 
Graham, C. B., van Verseveld, W., Barnard, H. R., and McDonnell, J. J.: Estimating the deep seepage component of the hillslope and catchment water balance within a measurement uncertainty framework, Hydrol. Process., 24, 3631-3647, https://doi.org/10.1002/hyp.7788, 2010.

Grecchi, R. C., Gwyn, Q. H. J., Bénié, G. B., Formaggio, A. R., and Fahl, F. C.: Land use and land cover changes in the Brazilian Cerrado: A multidisciplinary approach to assess the impacts of agricultural expansion, Appl. Geogr., 55, 300-312, https://doi.org/10.1016/j.apgeog.2014.09.014, 2014.

Guarenghi, M. M. and Walter, A.: Assessing potential impacts of sugarcane production on water resources: A case study in Brazil, Biofuel. Bioprod. Bior., 10, 699-709, https://doi.org/10.1002/bbb.1680, 2016.

Han, D., Currell, M. J., Cao, G., and Hall, B.: Alterations to groundwater recharge due to anthropogenic landscape change, J. Hydrol., 554, 545-557, https://doi.org/10.1016/j.jhydrol.2017.09.018, 2017.

Hernandes, T. A. D., Scarpare, F. V., and Seabra, J. E. A.: Assessment of the recent land use change dynamics related to sugarcane expansion and the associated effects on water resources availability, J. Clean Prod., 197, 1328-1341, https://doi.org/10.1016/j.jclepro.2018.06.297, 2018a.

Hernandes, T. A. D., Scarpare, F. V., and Seabra, J. E. A.: Assessment of impacts on basin stream flow derived from medium-term sugarcane expansion scenarios in Brazil, Agr. Ecosyst. Environ., 259, 11-18, https://doi.org/10.1016/j.agee.2018.02.026, 2018 b.

Kakatkar, R., Gnanaseelan, C., Deepa, J. S., Chowdary, J., and Parekh, A.: Role of ocean-atmosphere interactions in modulating the 2016 La Niña like pattern over the tropical Pacific, Dynam. Atmos. Oceans, 83, 100-110, https://doi.org/10.1016/j.dynatmoce.2018.07.003, 2018.

Klink, C. A. and Machado, R. B.: Conservation of the Brazilian Cerrado, Conserv Biol, 19, 707-713, https://doi.org/10.1111/j.15231739.2005.00702.x, 2005.

Krishnaswamy, J., Bonell, M., Venkatesh, B., Purandara, B. K., Rakesh, K. N., Lele, S., Kiran, M. C., Reddy, V., and Badiger, S.: The groundwater recharge response and hydrologic services of tropical humid forest ecosystems to use and reforestation: Support for the "infiltrationevapotranspiration trade-off hypothesis", J. Hydrol., 498, 191-209, https://doi.org/10.1016/j.jhydrol.2013.06.034, 2013.

Lamparter, G., Nobrega, R. L. B., Kovacs, K., Amorim, R. S., and Gerold, G.: Modelling hydrological impacts of agricultural expansion in two macro-catchments in Southern Amazonia, Brazil, Reg. Environ. Change, 18, 91-103, https://doi.org/10.1007/s10113-016-1015-2, 2016.

Lapola, D. M., Martinelli, L. A., Peres, C. A., Ometto, J. P. H. B., Ferreira, M. E., Nobre, C. A., Aguiar, A. P. D., Bustamante, M. M. C., Cardoso, M. F., Costa, M. H., Joly, C. A., Leite, C. C., Moutinho, P., Sampaio, G., Strassburg, B. B. N., and Vieira, I. C. G.: Pervasive transition of the Brazilian land-use system, Nat. Clim. Change, 4, 27-35, https://doi.org/10.1038/nclimate2056, 2013.

Leal, M. R. L. V., Horta Nogueira, L. A., and Cortez, L. A. B.: Land demand for ethanol production, Appl. Energ., 102, 266271, https://doi.org/10.1016/j.apenergy.2012.09.037, 2013.

Leite, M. B., Xavier, R. O., Oliveira, P. T. S., Silva, F. K. G., and Silva Matos, D. M.: Groundwater depth as a constraint on the woody cover in a Neotropical Savanna, Plant Soil, 426, 1-15, https://doi.org/10.1007/s11104-018-3599-4, 2018.

Loarie, S. R., Lobell, D. B., Asner, G. P., Mu, Q., and Field, C. B.: Direct impacts on local climate of sugarcane expansion in Brazil, Nat. Clim. Change, 1, 105-109, https://doi.org/10.1038/nclimate1067, 2011.

Lucas, M., Oliveira, P. T. S., Melo, D. C. D., and Wendland, E.: Evaluation of remotely sensed data for estimating recharge to an outcrop zone of the Guarani Aquifer System (South America), Hydrogeol. J., 23, 961-969, https://doi.org/10.1007/s10040-0151246-1, 2015.

Lucas, M. and Wendland, E.: Recharge estimates for various land uses in the Guarani Aquifer System outcrop area, Hydrolog. Sci. J., 61, 1253-1262, https://doi.org/10.1080/02626667.2015.1031760, 2015.

Manzione, R. L., Soldera, B. C., and Wendland, E. C.: Groundwater system response at sites with different agricultural land uses: case of the Guarani Aquifer outcrop area, Brotas/SP-Brazil, Hydrolog. Sci. J., 62, 28-35, https://doi.org/10.1080/02626667.2016.1154148, 2017.

Marris, E.: Conservation in Brazil: The forgotten ecosystem, Nature, 437, 944-945, 2005.

Meister, S., Nobrega, R. L. B., Rieger, W., Wolf, R., and Gerold, G.: Process-based modelling of the impacts of land use change on the water balance in the Cerrado Biome (Rio das Mortes, Brazil), Erdkunde, 71, 241-266, https://doi.org/10.3112/erdkunde.2017.03.06, 2017.

Melo, D. D. C. D., Scanlon, B. R., Zhang, Z., Wendland, E., and Yin, L.: Reservoir storage and hydrologic responses to droughts in the Paraná River basin, south-eastern Brazil, Hydrol. Earth Syst. Sci., 20, 4673-4688, https://doi.org/10.5194/hess-20-46732016, 2016.

Montgomery, D. C.: Design and Analysis of Experiments, John Wiley \& Sons, 752 pp., 2008.

Mwango, S. B., Msanya, B. M., Mtakwa, P. W., Kimaro, D. N., Deckers, J., and Poesen, J.: Effectiveness OF Mulching UnderMirabain Controlling Soil Erosion, Fertility Restoration and Crop Yield in the Usambara Mountains, Tanzania, Land Degrad. Dev., 27, 1266-1275, https://doi.org/10.1002/ldr.2332, 2016.

Nacinovic, M. G. G., Mahler, C. F., and Avelar, A. D. S.: Soil erosion as a function of different agricultural land use in Rio de Janeiro, Soil Till. Res., 144, 164-173, https://doi.org/10.1016/j.still.2014.07.002, 2014.

Nearing, M. A., Govers, G., and Norton, L. D.: Variability in Soil Erosion Data from Replicated Plots, Soil Sci. Soc. Am. J., 63, 1829-1835, https://doi.org/10.2136/sssaj1999.6361829x, 1999.

Nobrega, R. L. B., Guzha, A. C., Torres, G. N., Kovacs, K., Lamparter, G., Amorim, R. S. S., Couto, E., and Gerold, G.: Effects of conversion of native cerrado vegetation to pasture on soil hydro-physical properties, evapotranspiration and streamflow on the Amazonian agricultural frontier, Plos One, 12, e0179414, https://doi.org/10.1371/journal.pone.0179414, 2017.

Oishi, A. C., Oren, R., Novick, K. A., Palmroth, S., and Katul, G. G.: Interannual Invariability of Forest Evapotranspiration and Its Consequence to Water Flow Downstream, Ecosystems, 13, 421436, https://doi.org/10.1007/s10021-010-9328-3, 2010.

Oliveira, L. C.: Erosão hídrica e alguns processos hidrológicos em plantios de pinus, mata e campo nativos e estrada florestal, $\mathrm{PhD}$, 
Ciências Agrárias, Universidade do Estado de Santa Catarina, Lages, SC, 96 pp., 2012.

Oliveira, P. T. S.: Balanço hídrico e erosão do solo em mata nativa do bioma Cerrado, PhD, Departamento de Hidráulica e Saneamento - Escola de Engenharia de São Carlos, Universidade de São Paulo, São Carlos, SP, 2014.

Oliveira, P. T. S., Nearing, M. A., Moran, M. S., Goodrich, D. C., Wendland, E., and Gupta, H. V.: Trends in water balance components across the Brazilian Cerrado, Water Resour. Res., 50, 7100-7114, https://doi.org/10.1002/2013WR015202, 2014.

Oliveira, P. T. S., Wendland, E., Nearing, M. A., Scott, R. L., Rosolem, R., and da Rocha, H. R.: The water balance components of undisturbed tropical woodlands in the Brazilian cerrado, Hydrol. Earth Syst. Sci., 19, 2899-2910, https://doi.org/10.5194/hess-19-2899-2015, 2015.

Oliveira, P. T. S., Nearing, M. A., Hawkins, R. H., Stone, J. J., Rodrigues, D. B. B., Panachuki, E., and Wendland, E.: Curve number estimation from Brazilian Cerrado rainfall and runoff data, J. Soil Water Conserv., 71, 420-429, https://doi.org/10.2489/jswc.71.5.420, 2016.

Oliveira, P. T. S., Leite, M. B., Mattos, T., Nearing, M. A., Scott, R. L., de Oliveira Xavier, R., da Silva Matos, D. M., and Wendland, E.: Groundwater recharge decrease with increased vegetation density in the Brazilian cerrado, Ecohydrology, 10, e1759, https://doi.org/10.1002/eco.1759, 2017.

Oliveira, R. S., Bezerra, L., Davidson, E. A., Pinto, F., Klink, C. A., Nepstad, D. C., and Moreira, A.: Deep root function in soil water dynamics in cerrado savannas of central Brazil, Funct. Ecol., 19, 574-581, https://doi.org/10.1111/j.1365-2435.2005.01003.x, 2005.

Paiva, R. C. D., Collischonn, W., and Buarque, D. C.: Validation of a full hydrodynamic model for large-scale hydrologic modelling in the Amazon, Hydrol. Process., 27, 333-346, https://doi.org/10.1002/hyp.8425, 2013.

Pereira, A. R.: The Priestley-Taylor parameter and the decoupling factor for estimating reference evapotranspiration, Agr. Forest Meteorol., 125, 305-313, https://doi.org/10.1016/j.agrformet.2004.04.002, 2004.

Pimentel, D., Harvey, C., Resosudarmo, P., Sinclair, K., Kurz, D., McNair, M., Crist, S., Shpritz, L., Fitton, L., and Saffouri, R.: Environmental and economic costs of soil erosion and conservation benefits, Science, 267, 1117-1122, 1995.

Priestley, C. H. B. and Taylor, R. J.: On the Assessment of Surface Heat Flux and Evaporation Using Large-Scale Parameters, Mon. Weather Rev., 100, 81-92, https://doi.org/10.1175/15200493(1972)1000081:OTAOSH>2.3.CO;2, 1972.

Rawitscher, F.: The Water Economy of the Vegetation of the "Campos Cerrados" in Southern Brazil, J. Ecol., 36, 237-268, https://doi.org/10.2307/2256669, 1948.

Refsgaard, J. C., van der Sluijs, J. P., Højberg, A. L., and Vanrolleghem, P. A.: Uncertainty in the environmental modelling process - A framework and guidance, Environ. Modell. Softw., 22, 1543-1556, https://doi.org/10.1016/j.envsoft.2007.02.004, 2007.

Reys, P., Camargo, M. G. G., Grombone-Guarantini, M. T., Teixeira, A. P., Assis, M. A., and Morellato, L. P. C.: Estrutura e composição florística de um Cerrado sensu stricto e sua importância para propostas de restauração ecológica, Hoehnea, 40, 449-464, 2013.
Richards, L. A.: Capillary conduction of liquids through porous mediums, Physics, 1, 318-333, https://doi.org/10.1063/1.1745010, 1931.

Ritchie, J. T.: Model for predicting evaporation from a row crop with incomplete cover, Water Resour. Res., 8, 1204-1213, https://doi.org/10.1029/WR008i005p01204, 1972.

Rodrigues, N., Losekann, L., and Silveira Filho, G.: Demand of automotive fuels in Brazil: Underlying energy demand trend and asymmetric price response, Energ. Econ., 74, 644-655, https://doi.org/10.1016/j.eneco.2018.07.005, 2018.

Sadeghi, S. H. R., Seghaleh, M. B., and Rangavar, A. S.: Plot sizes dependency of runoff and sediment yield estimates from a small watershed, Catena, 102, 55-61, https://doi.org/10.1016/j.catena.2011.01.003, 2013.

Sakai, R. K., Fitzjarrald, D. R., Moraes, O. L. L., Staebler, R. M., Acevedo, O. C., Czikowsky, M. J., Silva, R. d., Brait, E., and Miranda, V.: Land-use change effects on local energy, water, and carbon balances in an Amazonian agricultural field, Global Change Biol., 10, 895-907, https://doi.org/10.1111/j.15298817.2003.00773.x, 2004.

Saraiva, O. F., Cogo, N. P., and Mielniczuk, J.: Erosividade das chuvas e perdas por erosão em diferentes manejos de solo e coberturas vegetais, Pesqui. Agropecu. Bras., 16, 121-128, 1981.

Scanlon, B. R., Reedy, R. C., Stonestrom, D. A., Prudic, D. E., and Dennehy, K. F.: Impact of land use and land cover change on groundwater recharge and quality in the southwestern US, Global Change Biol., 11, 1577-1593, https://doi.org/10.1111/j.13652486.2005.01026.x, 2005.

Scott, R. L., Huxman, T. E., Barron-Gafford, G. A., Darrel Jenerette, G., Young, J. M., and Hamerlynck, E. P.: When vegetation change alters ecosystem water availability, Global Change Biol., 20, 2198-2210, https://doi.org/10.1111/gcb.12511, 2014.

Silva, M. A., Silva, M. L. N., Curi, N., Avanzi, J. C., and Leite, F. P.: Sistemas de manejo em plantios florestais de eucalipto e perdas de solo e água na região do Vale do Rio Doce, MG, Cienc. Florest., 21, 765-776, 2011.

Soares-Filho, B., Rajão, R., Macedo, M., Carneiro, A., Costa, W., Coe, M., Rodrigues, H., and Alencar, A.: Cracking Brazil's Forest Code, Science, 344, 363-364, https://doi.org/10.1126/science.1246663, 2014.

Strohmeier, S., Laaha, G., Holzmann, H., and Klik, A.: Magnitude and Occurrence Probability of Soil Loss: A Risk Analytical Approach for the Plot Scale For Two Sites in Lower Austria, Land Degrad. Dev., 27, 43-51, https://doi.org/10.1002/ldr.2354, 2016.

Su, C., Cheng, Z., Wei, W., and Chen, Z.: Assessing groundwater availability and the response of the groundwater system to intensive exploitation in the North China Plain by analysis of long-term isotopic tracer data, Hydrogeol. J., 26, 1401-1415, https://doi.org/10.1007/s10040-018-1761-y, 2018.

Tseng, C. L., Alves, M. C., and Crestana, S.: Quantifying physical and structural soil properties using X-ray microtomography, Geoderma, 318, 78-87, https://doi.org/10.1016/j.geoderma.2017.11.042, 2018.

Villalobos-Vega, R., Salazar, A., Miralles-Wilhelm, F., Haridasan, M., Franco, A. C., and Goldstein, G.: Do groundwater dynamics drive spatial patterns of tree density and diversity in Neotropical savannas?, J. Veg. Sci., 25, 1465-1473, https://doi.org/10.1111/jvs.12194, 2014. 
Vourlitis, G. L., Filho, N. P., Hayashi, M. M. S., de S. Nogueira, J., Caseiro, F. T., and Campelo, J. H.: Seasonal variations in the evapotranspiration of a transitional tropical forest of Mato Grosso, Brazil, Water Resour. Res., 38, 30-31, https://doi.org/10.1029/2000wr000122, 2002.

Wang, H., Tetzlaff, D., and Soulsby, C.: Modelling the effects of land cover and climate change on soil water partitioning in a boreal headwater catchment, J. Hydrol., 558, 520-531, https://doi.org/10.1016/j.jhydrol.2018.02.002, 2018.

Wang, Q. J.: The Genetic Algorithm and Its Application to Calibrating Conceptual Rainfall-Runoff Models, Water Resour. Res., 27, 2467-2471, https://doi.org/10.1029/91WR01305, 1991.

Wendland, E., Barreto, C., and Gomes, L. H.: Water balance in the Guarani Aquifer outcrop zone based on hydrogeologic monitoring, J. Hydrol., 342, 261-269, https://doi.org/10.1016/j.jhydrol.2007.05.033, 2007.

Wendt, R., Alberts, E., and Hjelmfelt, A.: Variability of runoff and soil loss from fallow experimental plots, Soil Sci. Soc. Am. J., 50, 730-736, 1986.
Wohl, E., Barros, A., Brunsell, N., Chappell, N. A., Coe, M., Giambelluca, T., Goldsmith, S., Harmon, R., Hendrickx, J. M. H., Juvik, J., McDonnell, J., and Ogden, F.: The hydrology of the humid tropics, Nat. Clim. Change, 2, 655-662, https://doi.org/10.1038/nclimate1556, 2012.

Youlton, C., Bragion, A. P., and Wendland, E.: Experimental evaluation of sediment yield in the first year after replacement of pastures by sugarcane, Cienc. Investig. Agrar., 43, 374-383, https://doi.org/10.4067/S0718-16202016000300005, 2016a.

Youlton, C., Wendland, E., Anache, J. A. A., Poblete-Echeverría, C., and Dabney, S.: Changes in erosion and runoff due to replacement of pasture land with sugarcane crops, Sustainability-Basel, 8, 685, https://doi.org/10.3390/su8070685, 2016b.

Zhao, C., Gao, J. E., Huang, Y., Wang, G., and Xu, Z.: The Contribution of Astragalus adsurgens Roots and Canopy to Water Erosion Control in the Water-Wind Crisscrossed Erosion Region of the Loess Plateau, China, Land Degrad. Dev., 28, 265-273, https://doi.org/10.1002/ldr.2508, 2017. 